\title{
Study on the establishment of a diversified National Ambient Noise Monitoring Network in seven major cities of India
}

\author{
N. Garg ${ }^{1, *}$, A. K. Sinha ${ }^{2}$, M. K. Sharma ${ }^{3}$, V. Gandhi ${ }^{2}$, R. M. Bhardwaj ${ }^{2}$, \\ A. B. Akolkar ${ }^{2}$ and R. K. Singh ${ }^{3}$ \\ ${ }^{1}$ CSIR-National Physical Laboratory, New Delhi 110 012, India \\ ${ }^{2}$ Central Pollution Control Board, Parivesh Bhawan, East Arjun Nagar, Delhi 110 032, India \\ ${ }^{3}$ Delhi Technological University, Delhi 110 042, India
}

We describe the diversified National Ambient Noise Monitoring Network (NANMN) set up across 7 major cities of India and covering 70 stations for continuous noise monitoring throughout the year. The annual average $L_{\text {day }}(06-22 \mathrm{~h})$ and $L_{\text {night }}(22-06 \mathrm{~h})$ values observed in 2015 for these 70 locations are described. Of these, 25 locations are in commercial zones, 12 in industrial, 16 in residential and 17 in silence zones. Each city has 10 noise monitoring stations installed for analysing environmental noise pollution levels round the clock $(24 \times 365 \mathrm{~h})$. The long-term noise monitoring shows that ambient noise levels are very high compared to the recommended standards for some sites and thus noise abatement measures are essentially required for controlling these levels. The present study is focused on evaluation, analysis and reporting of environmental noise pollution in seven major cities of India and is instrumental in planning for the noise abatement measures for controlling noise pollution in these cities. Such a noise monitoring network established in India is unique and one of the largest noise monitoring networks of its kind across the globe.

Keywords: Day equivalent level, day-night average sound level, National Ambient Noise Monitoring Network, night equivalent level.

NOISE pollution has become a serious concern over the past several years in India. With growing vehicular population and urbanization, it is imperative to monitor the ambient noise levels and devise suitable measures for control to avoid health hazards and annoyance faced by the community. The evidence for effects of environmental noise on health is strongest for annoyance, sleep and cognitive performance in adults and children. The occupational noise exposure also shows some association with high blood pressure ${ }^{1}$. There have been many such studies conducted so far on the noise exposure and corre-

*For correspondence. (e-mail: ngarg@nplindia.org) lation with human blood pressure ${ }^{2-5}$. Meta-analyses have been carried out to derive the exposure-response relationships that can be used for quantitative health impact assessments $^{6}$. The meta analysis of 24 cross-sectional studies on the relationship between road traffic noise and prevalence of hypertension reported an odds ratio (OR) of $1.07(95 \%$ confidence interval $(\mathrm{CI})=1.02-1.12$, $P<0.05)$ per $10 \mathrm{~dB}$ increase of $16 \mathrm{~h}$ day-time average road traffic noise level $\left(L_{\text {Aeq, } 16 \mathrm{~h}}\right)$ in the range of $<50$ to $>75 \mathrm{~dB}$ (refs 7, 8). In India, there have been limited studies carried out on correlating the effect of noise on human health. A recent study provides evidence that road traffic noise is a serious cause of concern ${ }^{9}$. The study infers that association between transportation noise exposure and cardiovascular disease is evident, but not at significant level. A similar study suggests epidemiological evidence that exposure to road traffic noise of $L_{\mathrm{den}}>65 \mathrm{~dB}(A)$ may be associated with coronary heart disease (CHD) in adult subjects ${ }^{10}$. Traffic noise is probably the most rigorous and pervasive type of noise pollution $^{11}$. Traffic noise is said to account for over 1 million healthy years of life lost annually to ill health and may lead to a disease burden that is second only in magnitude to that from air pollution ${ }^{12}$.

It is thus imperative to continuously monitor the ambient noise levels especially at the noisy sites in the cities to not only ascertain the magnitude of noise levels, but also take preventive actions to control them. The Central Pollution Control Board (CPCB), India has taken this issue seriously and therefore has established a pilot project on National Ambient Noise Monitoring network (NANMN) covering seven major cities of India. This programme was established initially in 2011 with 35 noise monitoring stations covering seven major metropolitan cities: Delhi, Lucknow, Kolkata, Mumbai, Hyderabad, Bengaluru and Chennai ${ }^{13}$. However, the strengthening of this network to 35 more stations in the same 7 metropolitan cities since November 2014 has been indispensable in analysing a wider noise scenario situation in the country and adoption of noise abatement measures for controlling noise pollution in India. 
It may be noted that although installation of 10 noise monitoring locations in each city is insufficient to represent the noise environment of the concerned cities, the present study is focused on the evaluation and analysis of continuous long-term noise levels obtained from these 70 stations so as to ascertain and analyse the status of ambient noise levels and planning for suitable measures to control. The ambient noise levels observed at the 10 sites can however be correlated with other sites lying in the same zone (commercial/residential/industrial/silence) as well having similar vehicular density moving on roads. The data acquired under the establishment of diversified network so established with special budgetary grant from the government of India is indispensable for accomplishing the following objectives of the present study:

- Ascertain the annual average ambient noise levels of 70 sites and compare them with ambient noise standards of India.

- Inculcate the awareness of general public towards the status of noise pollution and dissemination of information publicly through website, http://www. cpcbnoise.com.

- Ascertaining the noisy spots amongst these 70 sites and suggesting the need for abatement measures required if any.

- Ascertain whether the current ambient noise standards are suitable enough for residential areas and areas within silence zones.

- Analyse the difference of $L_{\text {day }}$ and $L_{\text {night }}$ levels to ascertain the severity of night noise levels as compared to the day levels.

- Annual increment or decrement in the ambient noise levels for each of these sites in comparison to previous years.

It may be noted here that the day equivalent level $L_{\text {day }}$ and night equivalent level $L_{\text {night }}$ is calculated from the $24 \mathrm{~h}$ noise data for each day of the year. The day-time is from 6 am to $10 \mathrm{pm}$, while the night time is considered from $10 \mathrm{pm}$ to $6 \mathrm{am}$. The current ambient air quality standards in respect of noise followed in India are in terms of $L_{\text {day }}$ and $L_{\text {night }}$ as shown in Table 1 . The silence zone is an area comprising not less than $100 \mathrm{~m}$ around hospitals, educational institutions, courts, religious places or any other area declared as such by the competent authority. Mixed categories of areas may be declared as one of the four mentioned categories in Table 1 by the competent authority $^{14}$.

\section{Establishment of diversified NANMN project}

The diversified NANMN project was established in 2014 covering 70 stations in 7 major cities of the country namely, Bengaluru, Chennai, Delhi, Hyderabad, Kolkata, Lucknow and Mumbai. The 70 locations under study were established in 7 cities of India with each state having 10 noise monitoring stations. The 70 locations cover 25 commercial sites, 16 residential sites, 17 sites in silence zones and 12 sites in industrial zone. The noise monitoring terminal manufactured and installed by Geónica Earth Sciences, Spain ${ }^{15,16}$ is an automated system consisting of a sound level meter traceable to the national standards for continuously measuring the ambient noise through the year at 70 locations under study. The sound level data so acquired is transmitted to National Noise Monitoring Centre (NNMC) located at CPCB Headquarters, Parivesh Bhawan, New Delhi where the data is received, processed and displayed. The details of the project establishment and instrumentation used are discussed in detail in Garg et al. ${ }^{13}$. In addition, a website application, http://www.cpcbnoise.com was developed to disseminate the data in real time to the public for generating awareness towards reducing the noise pollution in different parts of the country ${ }^{17}$. Figure 1 shows the establishment of diversified NANMN project with 70 noise monitoring stations installed all over India covering 7 major cities of India. The Noise Monitoring Network so established is unique and one of the largest of its kind across the globe. Figure 2 shows the noise monitoring stations at 10 sites in Bengaluru city as a typical example of the noise monitoring infrastructure installed under the NANMN project.

\section{Analysis of ambient noise levels}

Figure $3 a$ and $b$ shows the annual average day equivalent levels, $L_{\text {day }}$ and annual average night equivalent levels, $L_{\text {night }}$ at 70 locations spread across the seven major cities: Bengaluru, Chennai, Delhi, Hyderabad, Kolkata, Lucknow and Mumbai in the year 2015. The comparison of the annual average ambient levels, $L_{\text {day }}$ and $L_{\text {night }}$ for 35 noise monitoring stations installed across the 7 major cities in India for the past 5 years is shown in Table 2 (ref. 13). However for some sites like DTU (May to August), Civil lines (January), Mandir Marg (January and February) and Punjabi bagh (January to May) in Delhi city; Gomti Nagar, site of Lucknow city; the noise monitored data was not available for some months due to instrumentation

Table 1. Ambient air quality standards in respect of noise in India ${ }^{14}$

\begin{tabular}{llcc}
\hline & & \multicolumn{2}{c}{ Limits in $\mathrm{dB}(A) L_{\mathrm{eq}} *$} \\
\cline { 3 - 4 } Area code & $\begin{array}{c}\text { Category of } \\
\text { area/zone }\end{array}$ & Day time & Night time \\
\hline A & Industrial area & 75 & 70 \\
B & Commercial area & 65 & 55 \\
C & Residential area & 55 & 45 \\
D & Silence zone & 50 & 40 \\
\hline
\end{tabular}

${ }^{*} L_{\mathrm{eq}}$ denotes the time weighted average of the sound level in decibels in $A$ weighting. 


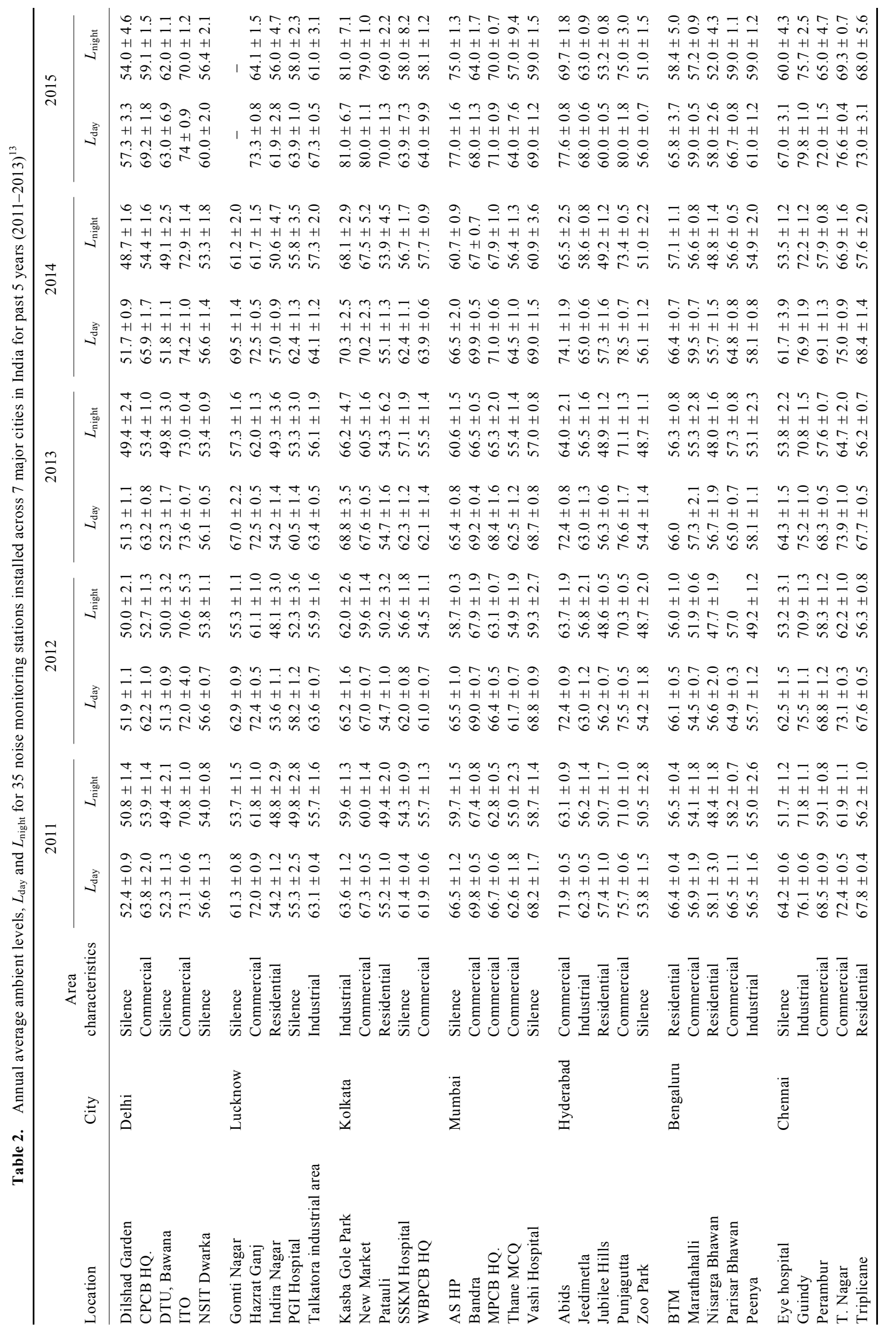




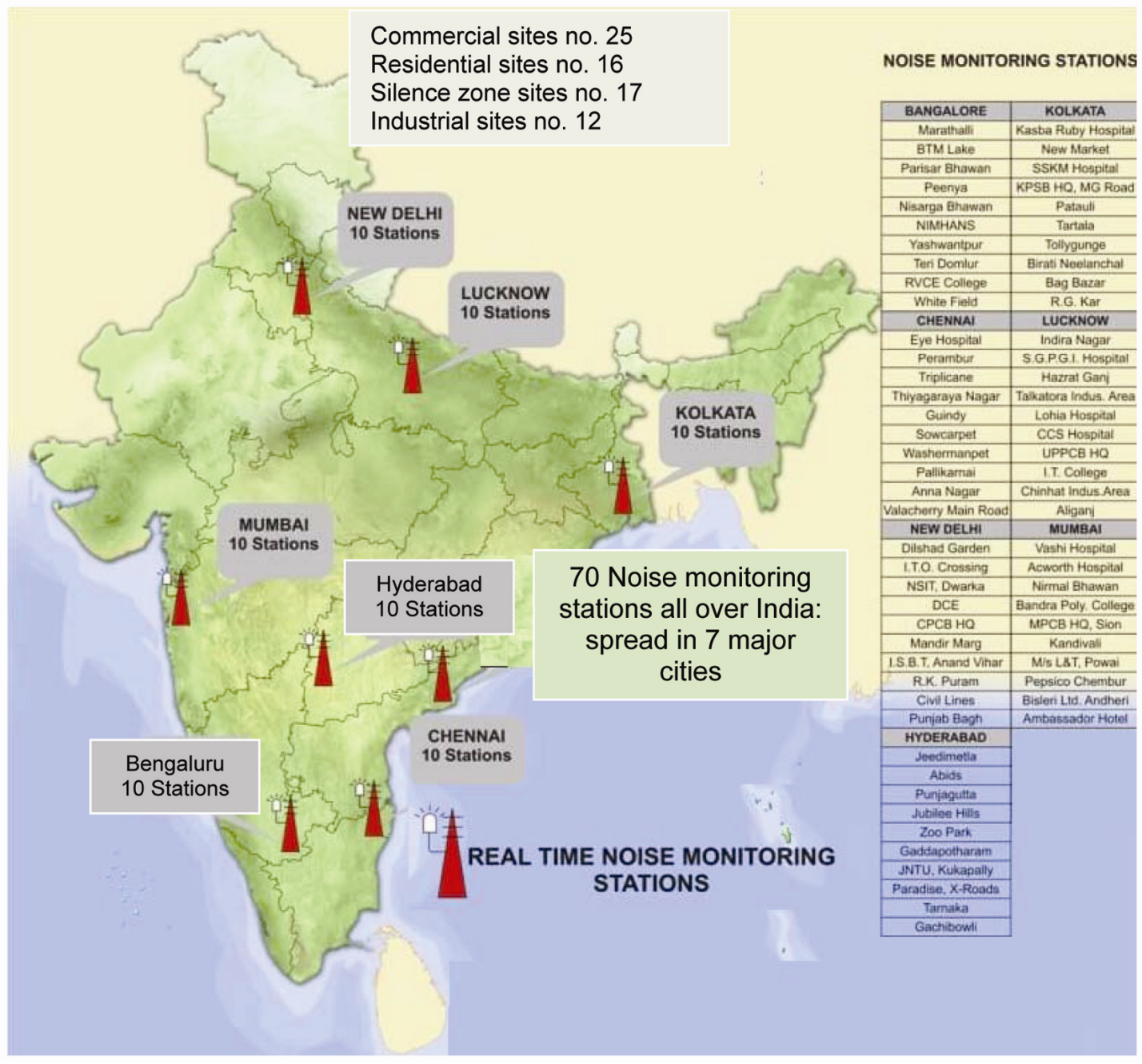

Figure 1. Establishment of diversified NANMN Project with 70 noise monitoring stations installed in the 7 major cities of $\operatorname{India}^{16}$

problems. Table 3 shows the annual average ambient levels, $L_{\text {day }}$ and $L_{\text {night }}$ for the newly installed 35 noise monitoring stations that include 11 commercial sites, 10 residential, 7 in silence zones and 7 in industrial zones established across the 7 major cities in India for year 2015. It can be observed from Table 3 that all the 7 industrial sites $(20 \%)$ out of the 35 new sites under consideration met the ambient noise standards.

\section{City wise analysis}

Bengaluru: The ambient noise levels have significantly increased over five years in Bengaluru city for the Peenya industrial site and that for night levels at Nisarga Bhawan residential site. The maximum increase in $L_{\text {day }}$ value since five years is $4.5 \mathrm{~dB}(A)$, while that for $L_{\text {night }}$ is $4.0 \mathrm{~dB}(A)$ for Peenya site. The ambient noise levels at newly monitored sites, Yeshwantpur, RVCE and NIMHANS are higher than the ambient noise standards. It was observed that Peenya and Whitefield industrial sites met the ambient noise standards. Figure $4 a$ and $b$ shows the monthly variation in day equivalent levels and night equivalent levels for the 10 sites in Bengaluru city. The variability in monthly day and night levels, $L_{\text {day }}$ and $L_{\text {night }}$ for Nisarga Bhawan, Domlur and NIMHANS sites is very high. It can be observed that for Yeshwantpur commercial site, the monthly average day levels are above $70 \mathrm{~dB}(A)$ throughout the year, while the monthly averaged night levels, $L_{\text {night }}$ are above $62 \mathrm{~dB}(A)$ throughout the year.

Chennai: The ambient noise levels have significantly increased over five years in Chennai city for Eye Hospital, Perambur, T. Nagar and Triplicane sites. It was observed that for Chennai city, 7 out of 10 sites made higher monthly averaged ambient day levels $\geq 65 \mathrm{~dB}(A)$ and monthly averaged ambient night noise levels $\geq 60 \mathrm{~dB}(A)$ in 2015. Seven sites registered annual averaged ambient night noise levels $\geq 65 \mathrm{~dB}(A)$. The maximum increase in $L_{\text {day }}$ value since five years was $5.2 \mathrm{~dB}(A)$, 

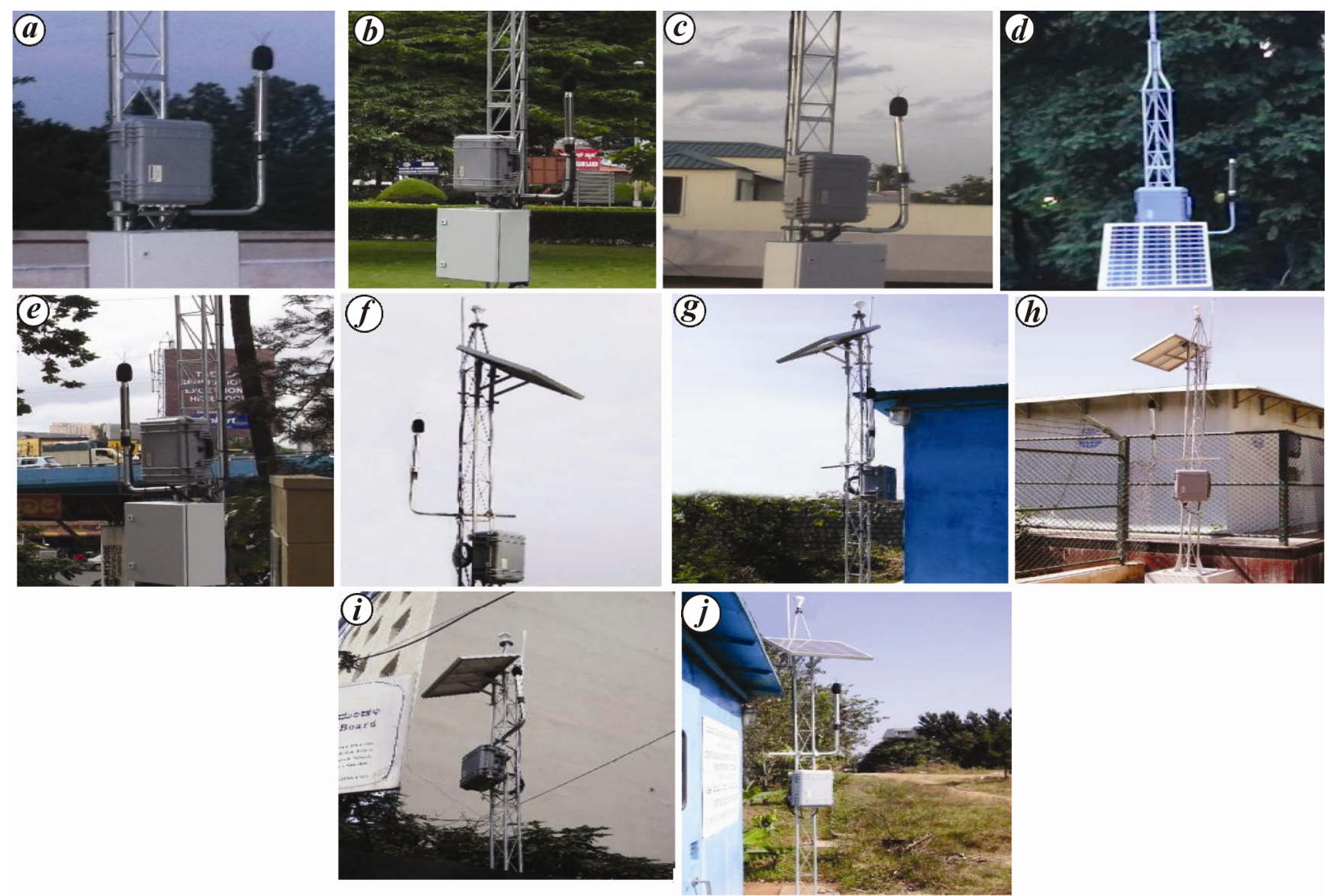

Figure 2. Noise monitoring stations at 10 sites in Bengaluru city established under NANMN project. $\boldsymbol{a}$, NIMHANS; $\boldsymbol{b}$, RVCE; $\boldsymbol{c}$, TERI Domlur; $\boldsymbol{d}$, Whitefield; $\boldsymbol{e}$, Yeshwanthpur; $\boldsymbol{f}$, BTM; $\boldsymbol{g}$, Marathahalli; $\boldsymbol{h}$, Nisarga Bhawan; $\boldsymbol{i}$, Parisar Bhawan; $\boldsymbol{j}$, Peenya.

while that for $L_{\text {night }}$ was $11.8 \mathrm{~dB}(A)$ for Triplicane residential area. The $L_{\text {day }}$ value since five years had increased by $2.8 \mathrm{~dB}(A)$, while that for $L_{\text {night }}$ it was $8.3 \mathrm{~dB}(A)$ for Eye Hospital area. The ambient noise levels at the newly monitored five sites, Pallikaranai, Velachery, Washermanpet, Anna Nagar and Sowcarpet are higher than the ambient noise standards. No site met the ambient noise standards of all the 10 sites under consideration. Figure $5 a$ and $b$ shows the monthly variation in equivalent day level and night levels for 10 sites in Chennai city. The variability in monthly night ambient noise levels was high for Eye Hospital, Perambur, Triplicane, Velachery, Washermanpet and Anna Nagar sites. The Guindy industrial site experienced high ambient noise levels. It was observed that for the Guindy site, the monthly averaged day levels were above $76 \mathrm{~dB}(A)$ throughout the year, while the monthly averaged night levels, $L_{\text {night }}$ were above $66 \mathrm{~dB}(A)$ throughout the year.

Delhi: It is seen from Table 2 that an increase of $\geq 5 \mathrm{~dB}(A)$ was noticed for Dilshad garden site, CPCB head quarters and DTU, Bawana sites. The ambient noise levels at ITO site were high compared to the ambient standards, although there was a marginal increase of
$0.9 \mathrm{~dB}(A)$ for $L_{\text {day }}$ and decrease in $L_{\text {night }}$ by $0.8 \mathrm{~dB}(A)$ over the past five years. It was observed that no site in Delhi region met the ambient noise standards. The Civil Lines, Anand Vihar, Mandir Marg and Punjabi Bagh stations had ambient levels high compared to standards. However, for Punjabi Bagh site Mandir Marg, Civil Lines and the DTU sites, the annual average ambient levels reported were based on the day and night levels acquired for some months (January to April and September to November for DTU site; June to December for Punjabi Bagh site; March to December for Mandir Marg site and February to December for Civil Lines site) only due to instrumentation problems. Figure $6 a$ and $b$ shows the monthly variation in equivalent day level and night level, $L_{\text {day }}$ and $L_{\text {night }}$ for the 10 sites in Delhi city. It was observed that variability in monthly day and night level was high for Dilshad garden, DTU, Civil lines, Anand Vihar and Mandir Marg sites. It was also observed that the ITO commercial site experienced high monthly average ambient day levels above $73 \mathrm{~dB}(A)$ and night levels above $69 \mathrm{~dB}(A)$ throughout the year.

Hyderabad: The ambient noise levels have significantly increased in Hyderabad city for two sites namely 

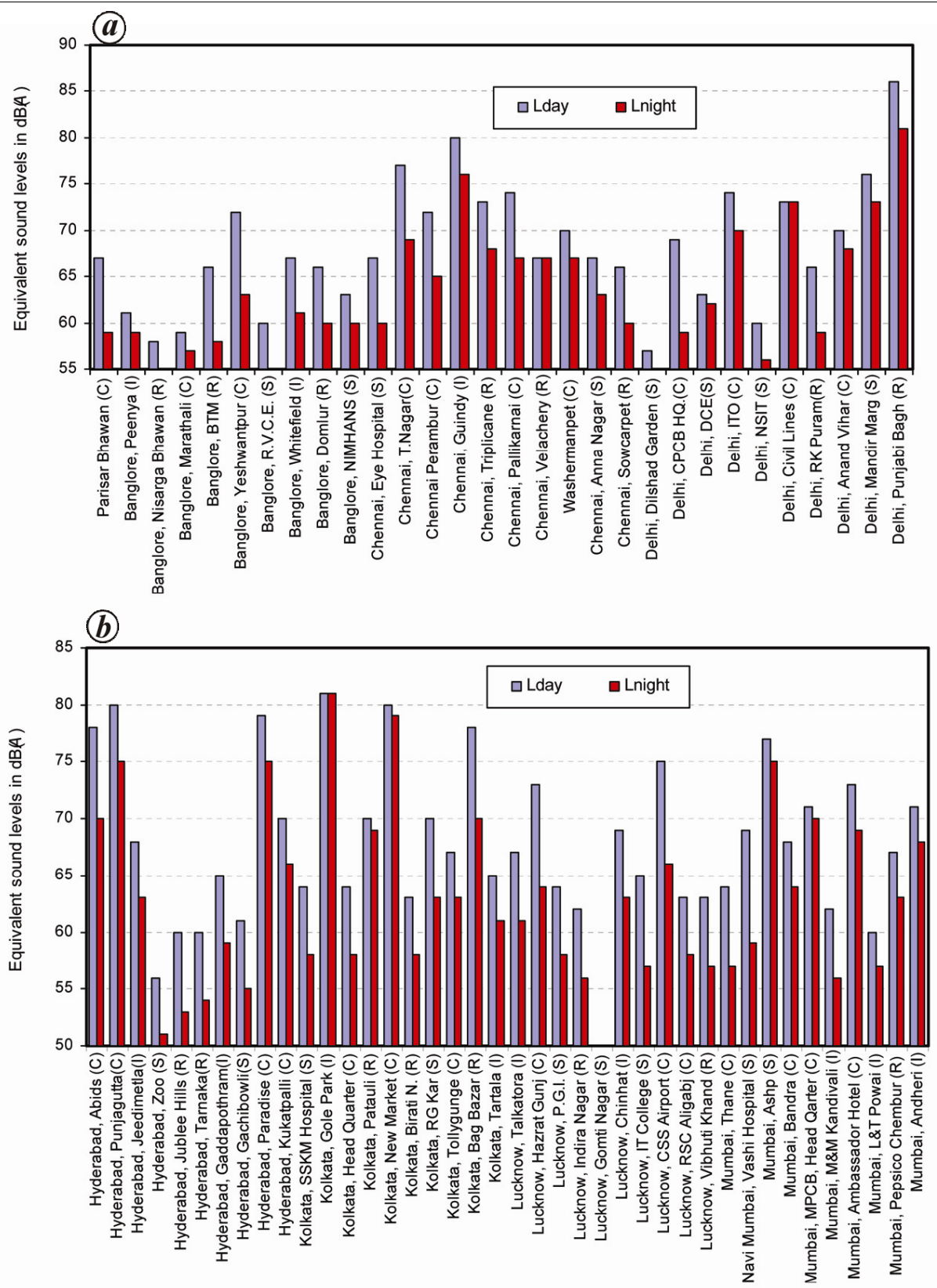

Figure 3. $\quad \boldsymbol{a}, L_{\text {day }}$ and $L_{\text {night }}$ levels at 30 locations spread across three major cities: Bengaluru, Chennai and Delhi in $2015 . \boldsymbol{b}, L_{\text {day }}$ and $L_{\text {night }}$ levels at 40 locations spread across four major cities: Hyderabad, Kolkata, Lucknow and Mumbai in 2015.

Abids and Jeedimetla compared to the year 2011 data. The $L_{\text {day }}$ levels have increased by $5.7 \mathrm{~dB}(A)$ and $L_{\text {night }}$ by $6.6 \mathrm{~dB}(A)$ over the past five years for Abids site, while for Jeedimetla site, the $L_{\text {day }}$ levels increased by $5.7 \mathrm{~dB}(A)$ and $L_{\text {night }}$ by $6.8 \mathrm{~dB}(A)$ over the past five years. The Jeedimetla and Gaddapothram industrial sites met the ambient noise standards. Some sites like Paradise, Kukatpalli, Abids and Punjagutta experienced higher ambient noise levels compared to the ambient noise standards. Figure $7 a$ and $b$ shows the monthly variation in day equivalent levels and night equivalent levels for 10 sites in Hyderabad city. It was also observed that Gachi- bowli site had high variability in night levels. The variability in night levels was higher for Tarnaka, Gaddapothram and Gachibowli sites. It was also observed that Abids and Paradise sites had monthly average ambient day levels higher than $75 \mathrm{~dB}(A)$ and monthly average night levels higher than $68 \mathrm{~dB}(A)$ throughout the year.

Kolkata: The ambient noise levels significantly increased in five years in Kolkata city for Kasba Gole Park site, Patauli and New Market area, where the $L_{\mathrm{day}}$ levels increased by $17.4 \mathrm{~dB}(A)$ and $L_{\text {night }}$ by $21.4 \mathrm{~dB}(A)$ over the past five years for Kasba Gole Park site. For 
Table 3. Annual average ambient levels, $L_{\text {day }}$ and $L_{\text {night }}$ for additional 35 noise monitoring stations installed across 7 major cities in India for the year 2015

\begin{tabular}{|c|c|c|c|c|}
\hline \multirow[b]{2}{*}{ Location } & \multirow[b]{2}{*}{ City } & \multirow[b]{2}{*}{ Area characteristics } & \multicolumn{2}{|c|}{2015} \\
\hline & & & $L_{\text {day }}$ & $L_{\text {night }}$ \\
\hline Civil Lines & Delhi & Commercial & $73.0 \pm 5.3$ & $73.0 \pm 5.3$ \\
\hline R. K. Puram & & Residential & $66.0 \pm 6.6$ & $59.0 \pm 7.6$ \\
\hline Anand Vihar & & Commercial & $70.0 \pm 3.3$ & $68.0 \pm 5.6$ \\
\hline Mandir Marg & & Silence & $76.0 \pm 5.8$ & $73.0 \pm 4.8$ \\
\hline Punjabi Bagh & & Residential & $86.0 \pm 1.1$ & $81.0 \pm 2.3$ \\
\hline Chinhat & Lucknow & Industrial & $68.6 \pm 5.5$ & $63.0 \pm 9.1$ \\
\hline IT College & & Silence & $65.0 \pm 4.1$ & $57.4 \pm 1.3$ \\
\hline CSS Airport & & Commercial & $74.7 \pm 8.6$ & $66.1 \pm 6.0$ \\
\hline RSC Aliganj & & Commercial & $63.0 \pm 0.8$ & $58.1 \pm 0.7$ \\
\hline Vibhuti Khand & & Residential & $63.4 \pm 1.3$ & $57.0 \pm 2.1$ \\
\hline Birati N & Kolkata & Residential & $63.2 \pm 2.6$ & $58.0 \pm 4.2$ \\
\hline R G Kar & & Silence & $70.0 \pm 8.6$ & $63.0 \pm 6.0$ \\
\hline Tollygunge & & Commercial & $66.8 \pm 0.5$ & $62.9 \pm 0.7$ \\
\hline Bagbazar & & Residential & $78.0 \pm 4.4$ & $70.0 \pm 2.5$ \\
\hline Tartala & & Industrial & $64.7 \pm 1.1$ & $61.1 \pm 1.7$ \\
\hline M\&M Kandivali & Mumbai & Industrial & $62.1 \pm 1.1$ & $55.8 \pm 1.6$ \\
\hline Ambassador Hotel & & Commercial & $73.1 \pm 0.9$ & $69.0 \pm 1.3$ \\
\hline L\&T Powai & & Industrial & $60.3 \pm 1.2$ & $57.4 \pm 1.5$ \\
\hline Pepsico Chembur & & Residential & $67.0 \pm 4.3$ & $63.0 \pm 7.8$ \\
\hline Andheri & & Industrial & $71.3 \pm 1.4$ & $67.6 \pm 0.8$ \\
\hline Tarnaka & Hyderabad & Residential & $60.2 \pm 1.2$ & $54.2 \pm 3.2$ \\
\hline Gaddapothram & & Industrial & $65.0 \pm 2.0$ & $59.0 \pm 3.5$ \\
\hline Gachibowli & & Silence & $60.9 \pm 2.2$ & $55.0 \pm 3.4$ \\
\hline Paradise & & Commercial & $79.1 \pm 0.9$ & $74.9 \pm 1.0$ \\
\hline Kukatpalli & & Commercial & $70.3 \pm 1.1$ & $66.4 \pm 1.0$ \\
\hline Yeshwantpur & Bengaluru & Commercial & $72.1 \pm 0.5$ & $63.4 \pm 0.7$ \\
\hline RVCE & & Silence & $60.1 \pm 0.7$ & $54.1 \pm 0.7$ \\
\hline Whitefield & & Industrial & $67.1 \pm 0.7$ & $61.2 \pm 0.6$ \\
\hline Domlur & & Residential & $66.0 \pm 3.3$ & $60.0 \pm 4.5$ \\
\hline NIMHANS & & Silence & $63.0 \pm 3.4$ & $60.0 \pm 5.1$ \\
\hline Pallikarnai & Chennai & Commercial & $73.8 \pm 0.6$ & $67.2 \pm 0.6$ \\
\hline Velachery & & Residential & $67.0 \pm 3.2$ & $67.0 \pm 9.4$ \\
\hline Washermanpet & & Commercial & $70.0 \pm 1.4$ & $67.0 \pm 5.7$ \\
\hline Anna Nagar & & Silence & $67.0 \pm 1.7$ & $63.0 \pm 4.6$ \\
\hline Sowcarpet & & Residential & $66.0 \pm 1.2$ & $60.0 \pm 2.7$ \\
\hline
\end{tabular}

Patauli site, $L_{\mathrm{day}}$ levels have increased by $14.8 \mathrm{~dB}(A)$ and $L_{\text {night }}$ by $19.6 \mathrm{~dB}(A)$ since the past five years. Similarly, the $L_{\mathrm{day}}$ levels had increased by $12.7 \mathrm{~dB}(A)$ and $L_{\text {night }}$ by $19.0 \mathrm{~dB}(A)$ over the past five years for New Market site. Many sites such as Kasba Gole Park site, New Market, SSKM hospital, Birati N, R G Kar, Tollygunge and Bagbazar experienced high ambient levels and thus need noise abatement measures for bringing these levels below the ambient standards. The Tartala industrial site met the ambient noise standards. Figure $8 a$ and $b$ shows the monthly variation in equivalent day and night levels for 10 sites in Kolkata city. It was observed that Kasba Gole park and R G Kar sites had high variability in day levels. The variability in night levels was higher for Kasba Gole Park, Birati N, R G Kar sites. It was also observed that Kasba Gole industrial site experienced high monthly averaged ambient day and night noise levels above
$71 \mathrm{~dB}(A)$ throughout the year. Similarly, the Bagbazar site experienced high ambient noise levels above $74 \mathrm{~dB}(A)$ for day levels throughout the year and above 68 $\mathrm{dB}(A)$ for $L_{\text {night }}$ throughout the year.

Lucknow: The ambient noise levels increased for Indira Nagar and PGI hospital site by more than $7 \mathrm{~dB}(A)$ over the past five years. It was observed that only Chinhat and Talkatora industrial sites met the ambient noise standards. The day equivalent level, $L_{\mathrm{day}}$ increased by $4.2 \mathrm{~dB}(A)$, while night equivalent level, $L_{\text {night }}$ increased by $5.3 \mathrm{~dB}(A)$ in the past five years for Talkatora industrial site. The Hazrat Ganj commercial site, IT College, CSS Airport and Vibhuti khand sites experienced high ambient levels compared to the ambient standards. The noise monitoring data for Gomti nagar site was not acquired due to instrumentation problems. Figure $9 a$ and $b$ 

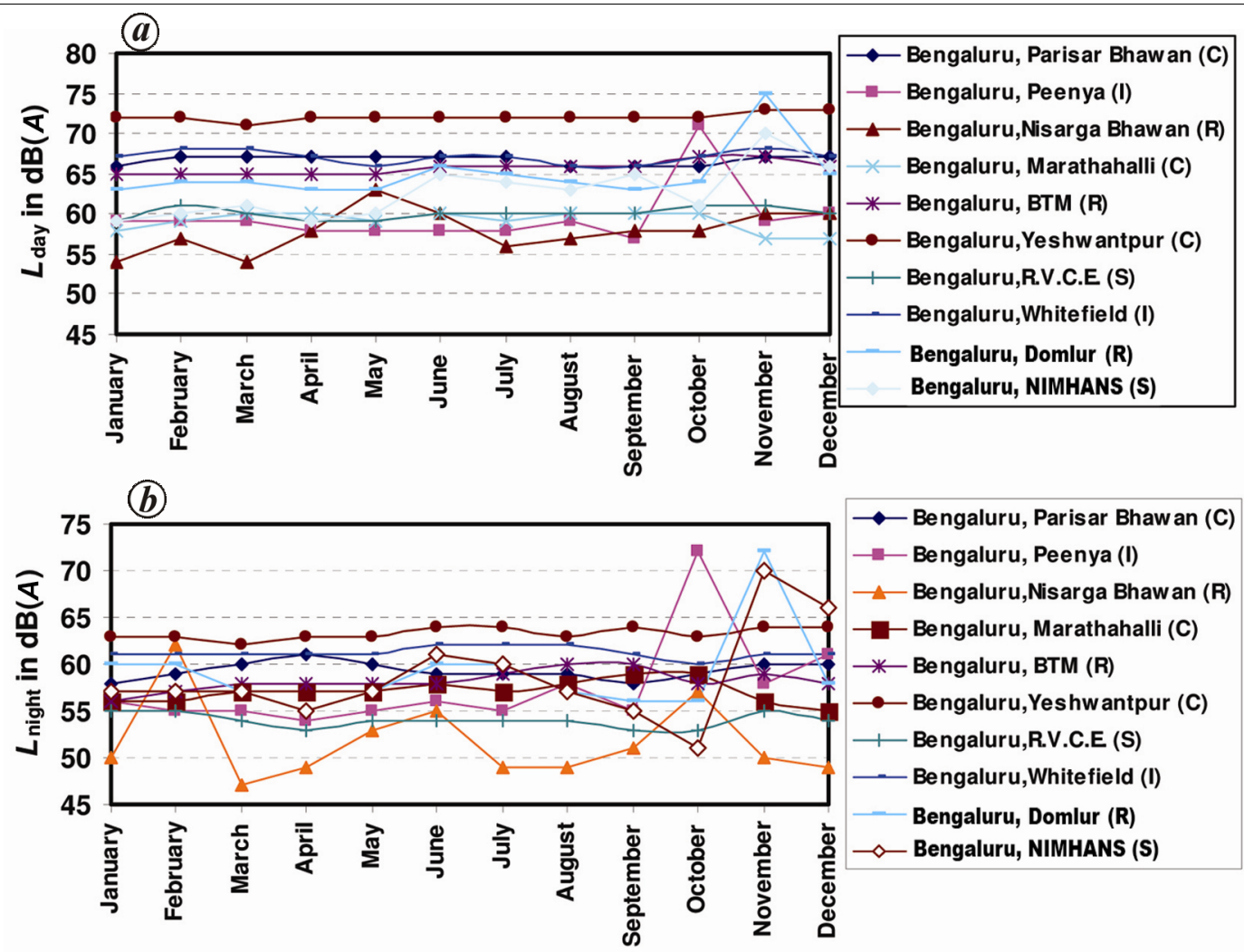

Figure 4. Monthly variation in (a) day equivalent level, $L_{\mathrm{day}}$ and (b) night equivalent level, $L_{\mathrm{night}}$ for 10 sites in Bengaluru city in 2015.
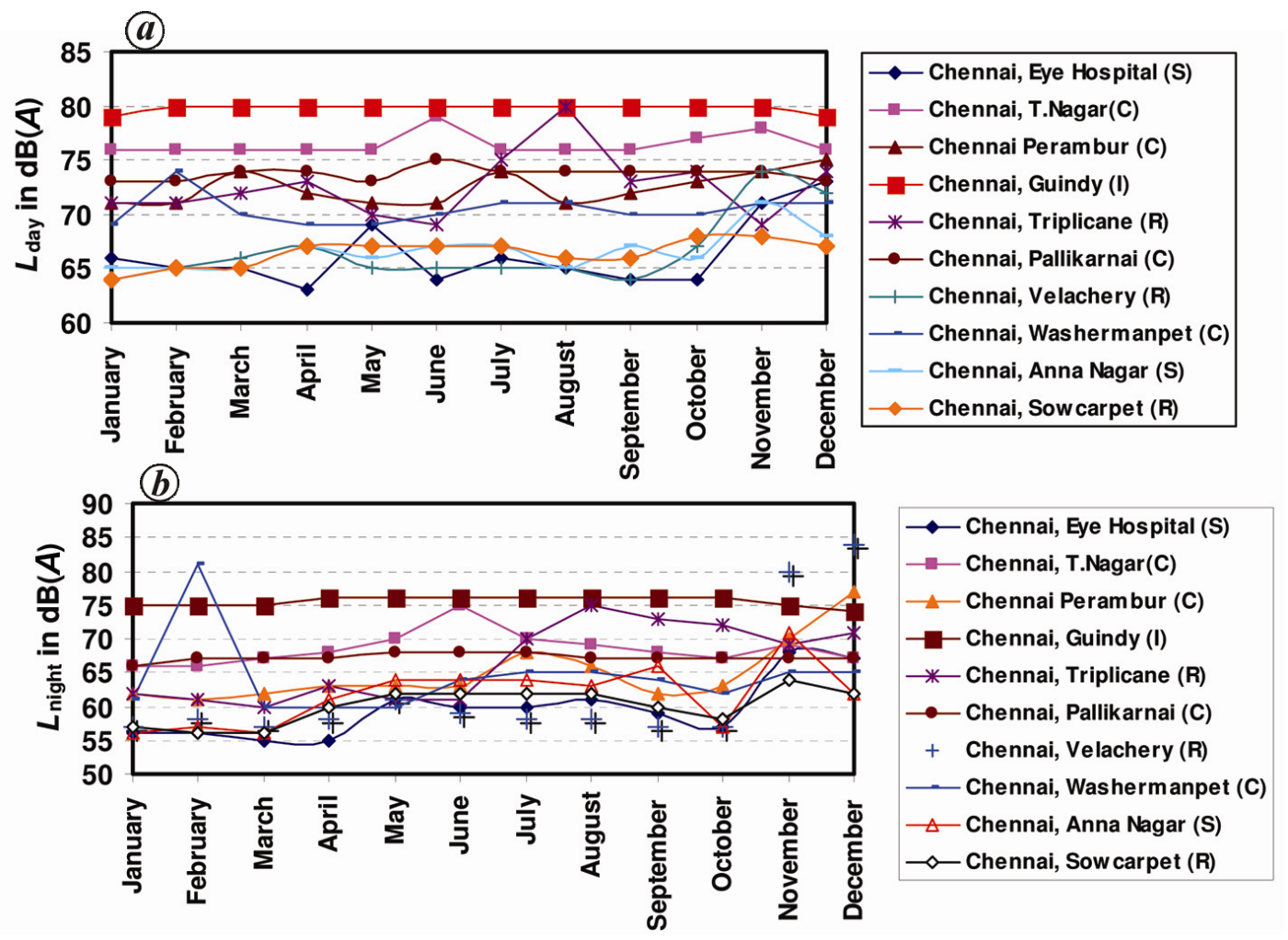

Figure 5. Monthly variation in (a) day equivalent level, $L_{\text {day }}$ and (b) night equivalent level, $L_{\text {night }}$ for 10 sites in Chennai city in 2015. 

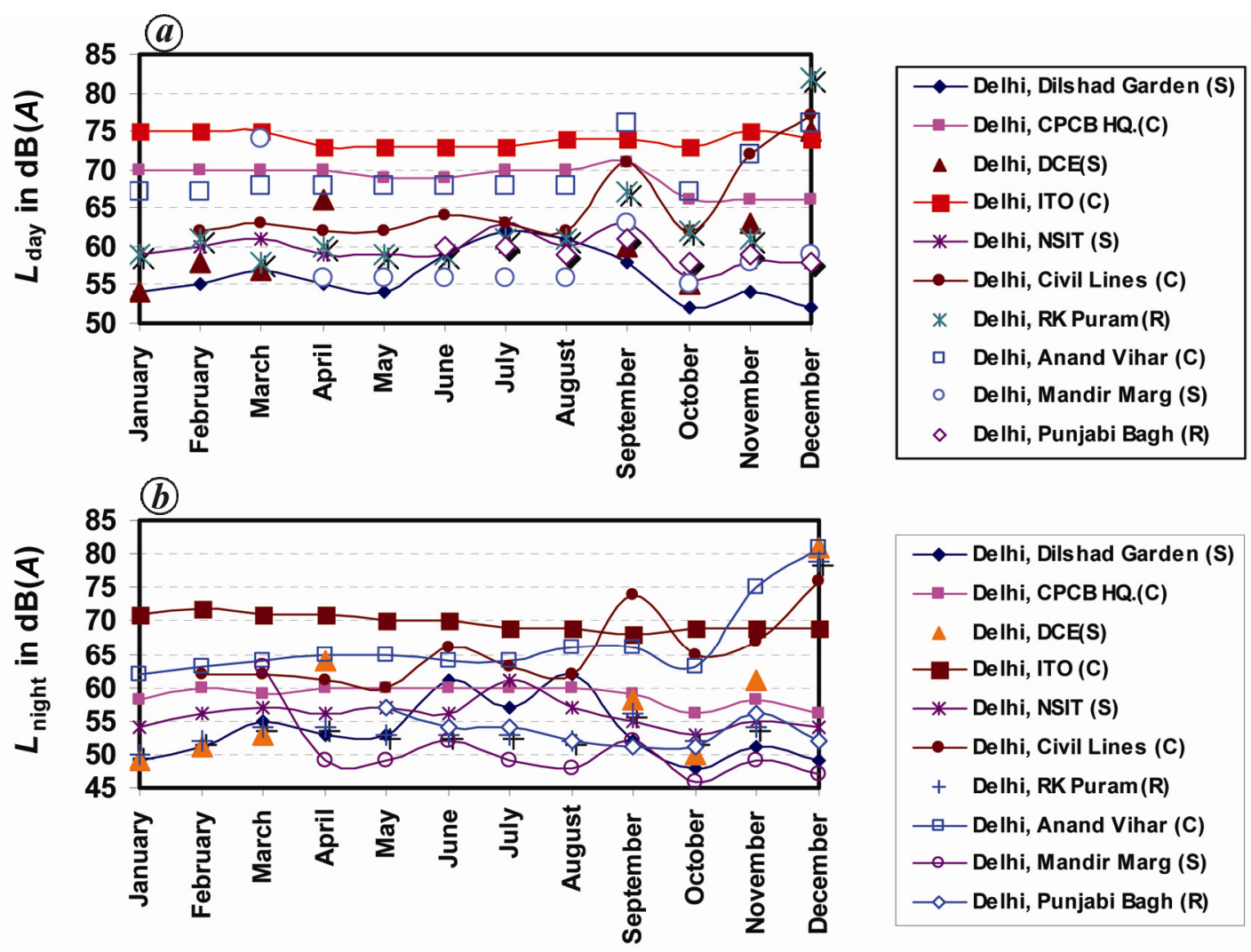

Figure 6. Monthly variation in (a) day equivalent level, $L_{\mathrm{day}}$ and $(\boldsymbol{b})$ night equivalent level, $L_{\mathrm{day}}$ for 10 sites in Delhi city in 2015 .
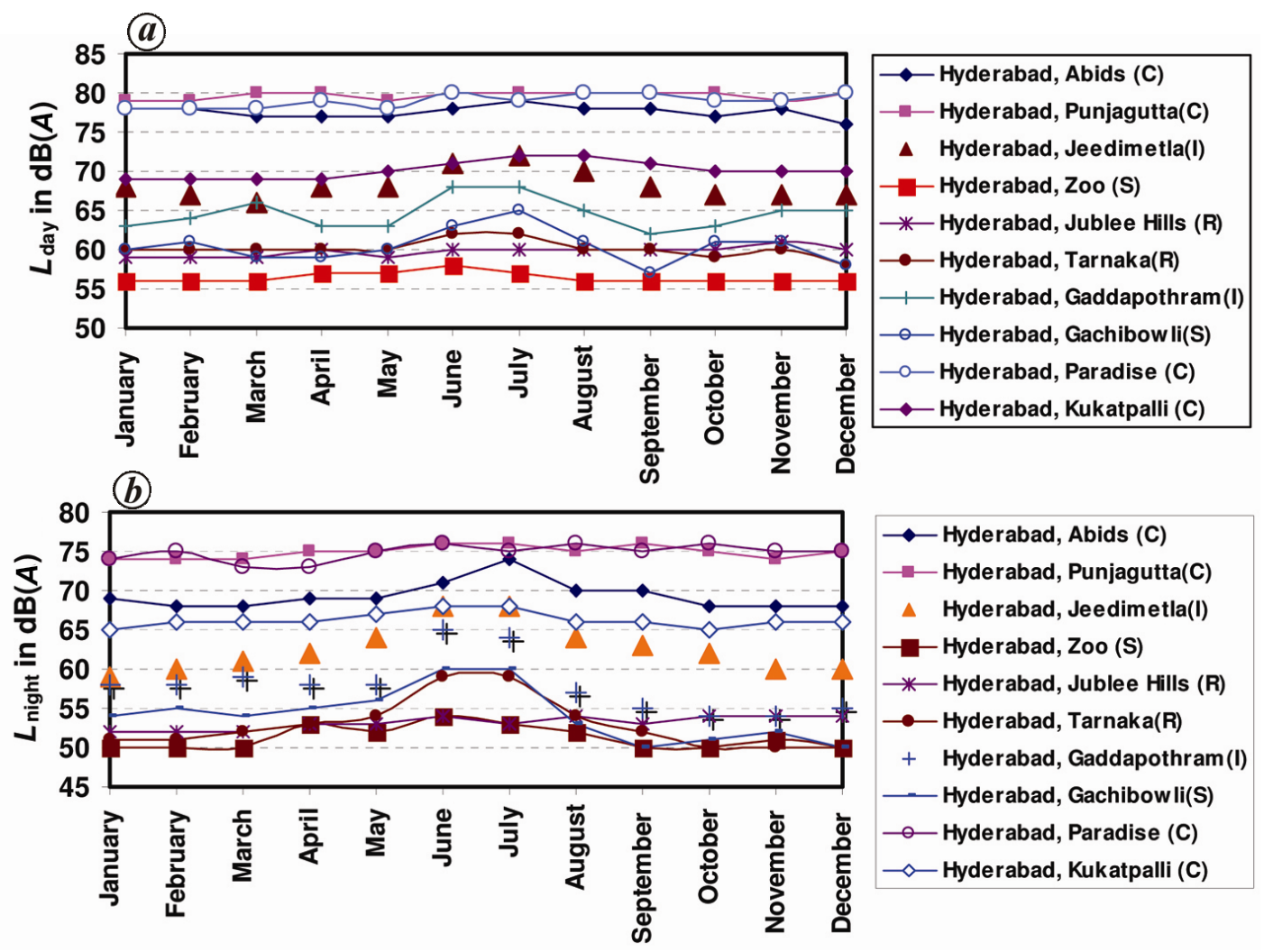

Figure 7. Monthly variation in (a) day equivalent level, $L_{\mathrm{day}}$ and $(\boldsymbol{b})$ night equivalent level, $L_{\mathrm{night}}$ for 10 sites in Hyderabad city in 2015. 

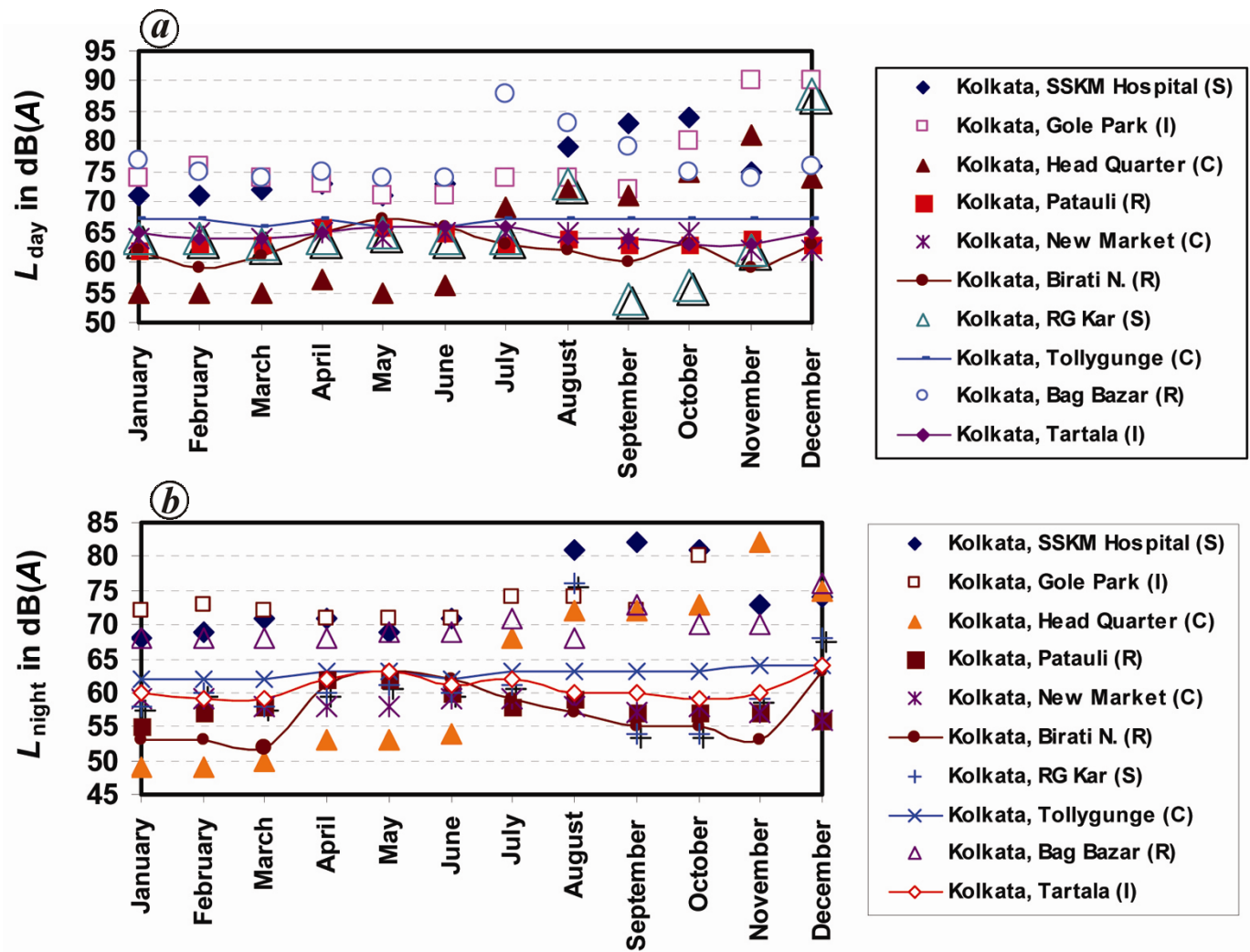

- Kolkata, SSKM Hospital (S)

口 Kolkata, Gole Park (I)

4 Kolkata, Head Quarter (C)

- Kolkata, Patauli (R)

* Kolkata, New Market (C)

$\longrightarrow$ Kolkata, Birati N. (R)

$+\quad$ Kolkata, RG Kar (S)

* Kolkata, Tollygunge (C)

$\triangle$ Kolkata, Bag Bazar (R)

$\multimap$ Kolkata, Tartala (I)

Figure 8. Monthly variation in (a) day equivalent level, $L_{\text {day }}$ and (b) night equivalent level, $L_{\text {night }}$ for 10 sites in Kolkata city in 2015 .
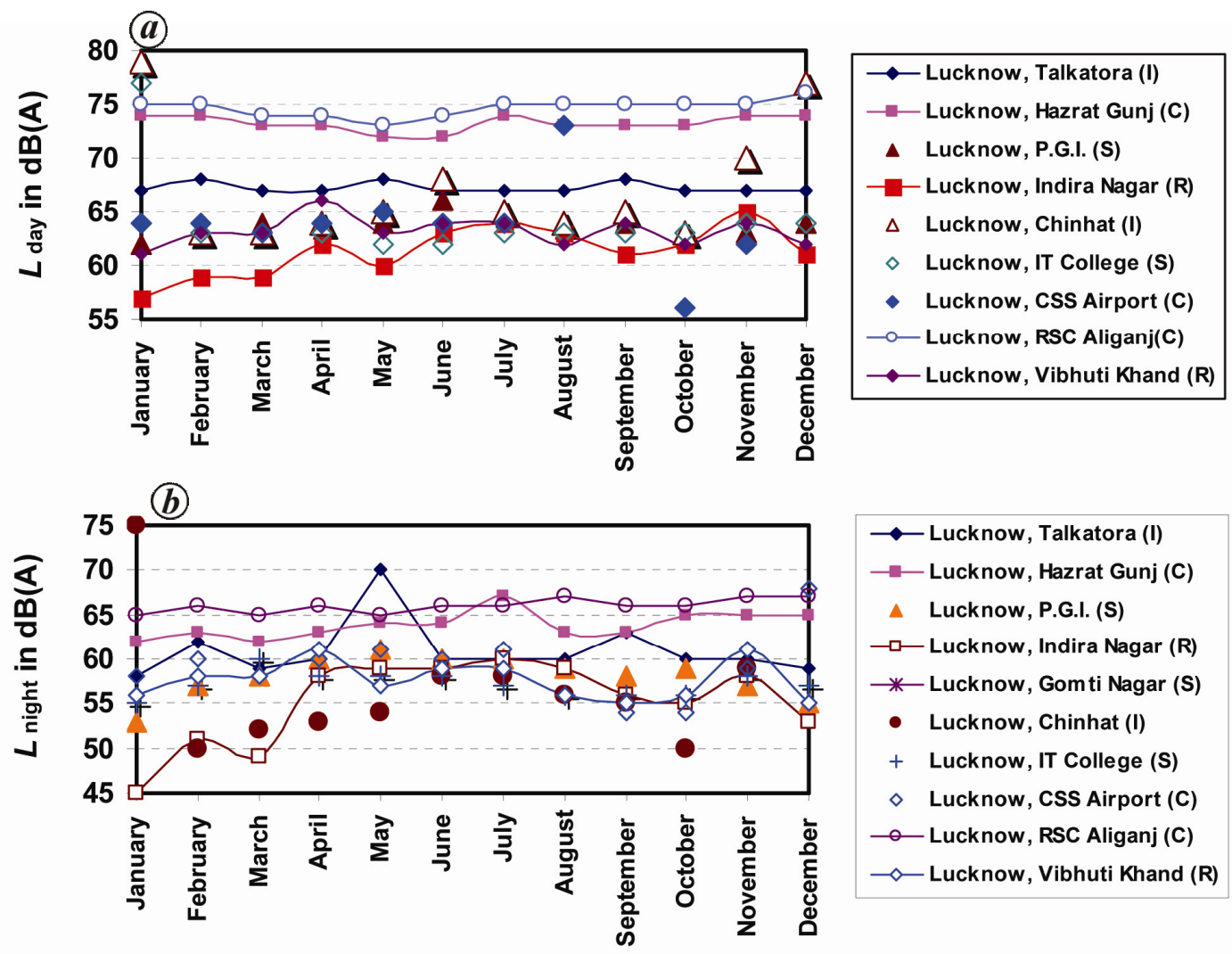

Figure 9. Monthly variation in (a) day equivalent level, $L_{\mathrm{day}}$ and $(\boldsymbol{b})$ night equivalent level, $L_{\mathrm{night}}$ for 10 sites in Lucknow city in 2015. 
RESEARCH ARTICLES

Table 4. Variation of $L_{\mathrm{day}}$ and $L_{\mathrm{night}}$ values; $L_{\mathrm{Aeq}, 24 \mathrm{~h}} ; L_{\mathrm{dn}}$ and difference $\left(L_{\mathrm{day}}-L_{\mathrm{night}}\right)$ values in $\mathrm{dB}(A)$ for different areas/zone in year 2015

\begin{tabular}{|c|c|c|c|c|c|c|c|c|c|c|c|}
\hline \multirow{2}{*}{$\begin{array}{l}\text { Category of } \\
\text { area/zone }\end{array}$} & \multicolumn{2}{|c|}{$L_{\text {day }}$} & \multicolumn{2}{|c|}{$L_{\text {night }}$} & \multicolumn{3}{|c|}{$\left(L_{\text {day }}-L_{\text {night }}\right)$} & \multicolumn{2}{|c|}{$L_{\text {Aeq, } 24 \mathrm{~h}}$} & \multicolumn{2}{|c|}{$L_{\mathrm{dn}}$} \\
\hline & Minimum & Maximum & Minimum & Maximum & Minimum & Average & Maximum & Minimum & Maximum & Minimum & Maximum \\
\hline $\begin{array}{l}\text { Industrial area } \\
\qquad(\text { no. of sites }=12)\end{array}$ & 60.3 & 81.0 & 56.0 & 81.0 & 0 & 4.3 & 6.0 & 59.2 & 81.0 & 63.7 & 87.0 \\
\hline $\begin{array}{l}\text { Commercial area } \\
\quad(\text { no. of sites }=25)\end{array}$ & 59.2 & 80.0 & 57.0 & 79.0 & 0 & 5.2 & 10.0 & 58.6 & 79.0 & 63.4 & 85.2 \\
\hline $\begin{array}{l}\text { Residential area } \\
\quad(\text { no. of sites }=16)\end{array}$ & 58.0 & 86.0 & 52.0 & 81.0 & 0 & 5.4 & 8.3 & 56.8 & 84.0 & 59.8 & 88.4 \\
\hline $\begin{array}{l}\text { Silence zone } \\
\quad(\text { no. of sites }=17)\end{array}$ & 56.0 & 77.0 & 51.0 & 75.0 & 0 & 4.8 & 10.0 & 54.9 & 76.4 & 58.4 & 81.4 \\
\hline
\end{tabular}
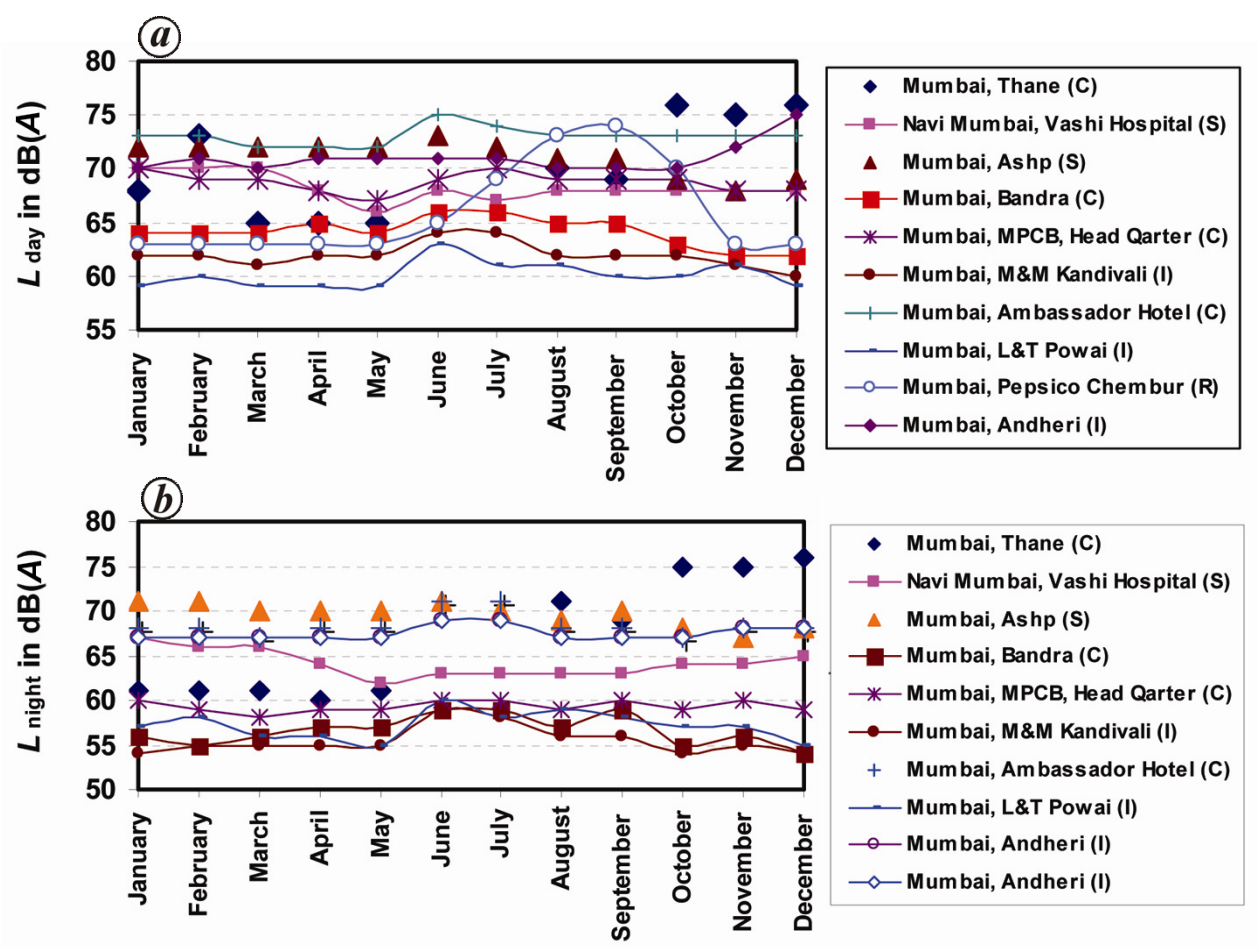

Figure 10. Monthly variation in (a) day equivalent level, $L_{\text {day }}$ and (b) night equivalent level, $L_{\text {night }}$ for 10 sites in Mumbai city in 2015.

shows the monthly variation in day and night levels for the 10 sites in Lucknow. The variability in monthly day level for Indira Nagar residential site and Chinhat industrial site was high. The variability in monthly night levels for Indira Nagar residential site and Chinhat sites was high. It was also observed that the Hazrat Ganj site experienced monthly average ambient day levels higher than $73 \mathrm{~dB}(A)$ and monthly average ambient night noise levels higher than $62 \mathrm{~dB}(A)$ throughout the year.

Mumbai: The ambient noise levels increased by $\geq 10 \mathrm{~dB}(A)$ in five years in Mumbai city for ASHP site. The Bandra commercial site experienced a decrease in the $L_{\text {day }}$ value by $1.8 \mathrm{~dB}(A)$ and that of $L_{\text {night }}$ value by $3.4 \mathrm{~dB}(A)$ compared to 2011 data. The M\&M Kandivali site, L\&T Powai and Andheri industrial sites met the ambient noise standards out of the 10 sites in the city under considera- tion. Some sites such as Ambassador Hotel, Pepsico Chembur, ASHP, Bandra, MPCB headquarters, Thane MCQ and Vashi hospital experienced higher ambient levels compared to the standards. Figure $10 a$ and $b$ shows the monthly variation in day and night levels for 10 sites in Mumbai city. The variability in monthly day and night levels was high for Pepsico Chembur and Thane MCQ sites. It was observed that Ambassador Hotel commercial site, and Andheri site have monthly averaged ambient day levels higher than $70 \mathrm{~dB}(A)$ and monthly averaged night noise levels higher than $67 \mathrm{~dB}(A)$ throughout the year.

\section{Zone wise analysis}

Table 4 shows the range of ambient noise levels, $L_{\text {day }}$ and $L_{\text {night }}$ values, $L_{\text {Aeq, } 24 \mathrm{~h}}$ and difference $\left(L_{\text {day }}-L_{\text {night }}\right)$ values 

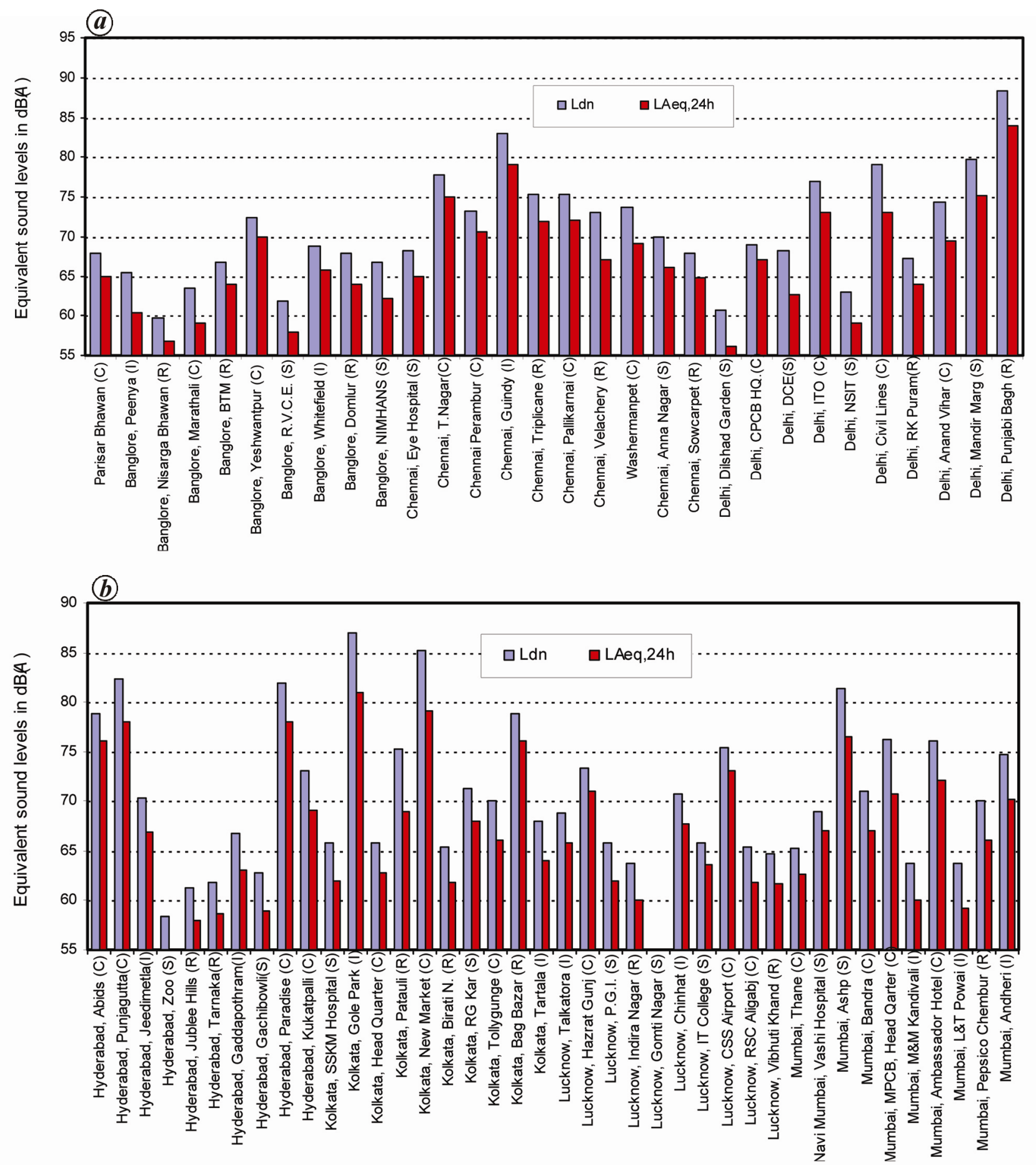

Figure 11. $\quad \boldsymbol{a}, L_{\mathrm{Aeq}, 24 \mathrm{~h}}$ and $L_{\mathrm{dn}}$ levels at 30 locations spread across three major cities: Bengaluru, Chennai and Delhi in $2015 . \boldsymbol{b}, L_{\mathrm{Aeq}, 24 \mathrm{~h}}$ and $L_{\mathrm{dn}}$ levels at 40 locations spread across four major cities: Hyderabad, Kolkata, Lucknow and Mumbai in 2015.

in $\mathrm{dB}(A)$ for different areas/zones in 2015. The $L_{\text {day }}$ levels varied from $60.3 \mathrm{~dB}(A)$ at $\mathrm{L} \& \mathrm{~T}$, Powai site in Mumbai to $81.0 \mathrm{~dB}(A)$ at Gole park site in Kolkata amongst all sites lying in the industrial zone. The night levels varied from $56.0 \mathrm{~dB}(A)$ at $\mathrm{M} \& \mathrm{M}$ Kandivali site to $81.0 \mathrm{~dB}(A)$ at Gole Park site in Kolkata for all sites lying in the industrial zone. For the noise monitored for 25 commercial sites, the $L_{\text {day }}$ levels varied from $59.2 \mathrm{~dB}(A)$ at Marathahalli site to $79.7 \mathrm{~dB}(A)$ at Punjagutta site, while the night levels, $L_{\text {night }}$ varied from $57.0 \mathrm{~dB}(A)$ at Thane and Marathahalli sites to $79.0 \mathrm{~dB}(A)$ at New Market site. The day levels varied from $58.0 \mathrm{~dB}(A)$ at Nisarga bhawan site to $86.0 \mathrm{~dB}(A)$ for Punjabi bagh site amongst the 16 sites lying in residential zone. The night levels varied from 


\section{RESEARCH ARTICLES}

Table 5. Frequency distribution of $L_{\mathrm{day}}$ and $L_{\mathrm{night}} ; L_{\mathrm{dn}}$ and $L_{\mathrm{Aeq}, 24 \mathrm{~h}}$ in $\mathrm{dB}(A)$ for seven major cities (70 sites) in year 2015

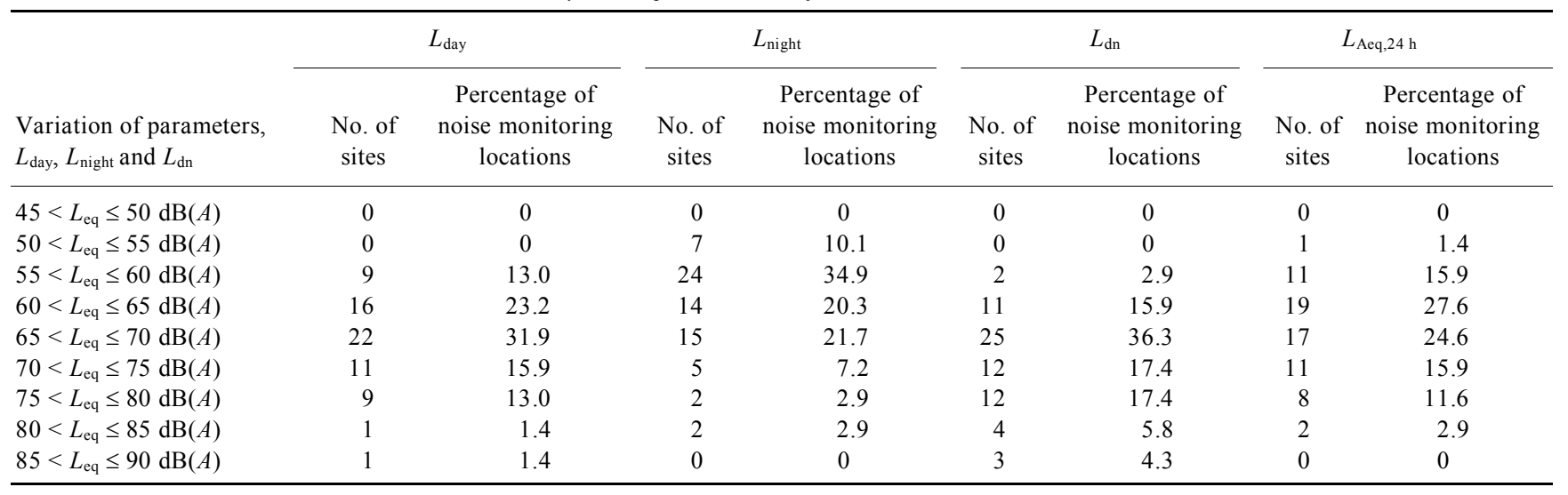

$52.0 \mathrm{~dB}(A)$ at Nisarga bhawan site to $81.0 \mathrm{~dB}(A)$ at Punjabi bagh site amongst the 16 sites lying in residential zone. For the 17 sites lying in silence zones, the $L_{\text {day }}$ levels varied from $56.0 \mathrm{~dB}(A)$ at Zoo site to $77.0 \mathrm{~dB}(A)$ at ASHP site. The night levels, $L_{\text {night }}$ varied from $51.0 \mathrm{~dB}(A)$ at Zoo site to $75.0 \mathrm{~dB}(A)$ at ASHP site. The analysis of day night average sound levels, $L_{\mathrm{dn}}$ revealed that Zoo site in Hyderabad city experienced the lowest level of $58.4 \mathrm{~dB}(A)$; while the Punjabi bagh residential site experienced the highest $L_{\mathrm{dn}}$ level of $88.4 \mathrm{~dB}(A)$. Also, the equivalent continuous sound level for $24 \mathrm{~h}, L_{\mathrm{Aeq}, 24 \mathrm{~h}}$ was observed to be of minimum value of $54.9 \mathrm{~dB}(A)$ at $\mathrm{Hy}$ derabad $\mathrm{Zoo}$ and the maximum value of $84.0 \mathrm{~dB}(A)$ for Punjabi bagh site. The analysis of $\left(L_{\text {day }}-L_{\text {night }}\right)$ in $\mathrm{dB}$ for these four zones revealed that for the industrial zone, only 5 out of 12 sites have this difference higher than $5 \mathrm{~dB}(A)$, which indicates that industrial sites have comparable night noise levels to the day noise levels. For sites lying in residential and silence zones, 8 out of 17 sites $(47 \%)$ in silence zone and 10 out of $16(62.5 \%)$ in residential zone have $\left(L_{\text {day }}-L_{\text {night }}\right)$ higher than $5 \mathrm{~dB}(A)$. Eleven commercial sites $(44 \%)$ out of 25 under consideration experienced $\left(L_{\text {day }}-L_{\text {night }}\right)$ higher than $5 \mathrm{~dB}(A)$.

\section{Overall noise scenario}

The $L_{\text {day }}$ and $L_{\text {night }}$ levels observed for 70 sites for 2015 revealed that only 10 industrial sites $(14.3 \%)$ met the ambient noise standards. The sites were Talkatora, Jeedimetla, Peenya, Chinhat, Tartala, M\&M Kandivali, L\&T Powai, Andheri, Gaddapothram and Whitefield. The situation was similar to that observed in 2014 noise monitoring data for 35 sites under consideration, where it was observed that 4 industrial sites met the ambient noise standards. Thus, no site lying in residential zone, or commercial zone or in silence zone qualified for the ambient noise standards. It was observed that 7 sites $(10 \%)$ met the target of $55 \mathrm{~dB} L_{\text {night }}$. The World Health Organization (WHO) considers the average nocturnal noise levels of $L_{\text {Aeq,outside }} 55 \mathrm{~dB}$ as an interim goal when the recommended guidelines value of $40 \mathrm{~dB}$ is not feasible in the short term ${ }^{18}$. It was observed that for Chennai city, seven sites had higher ambient day levels $\geq 65 \mathrm{~dB}(A)$ and ambient night noise levels $\geq 60 \mathrm{~dB}(A)$. For Mumbai city and six sites registered ambient day noise levels $\geq 65 \mathrm{~dB}(A)$ and night noise levels $\geq 60 \mathrm{~dB}(A)$. It was also observed that Delhi city had the least number of sites violating the criteria of day ambient noise levels higher than $65 \mathrm{~dB}(A)$ and night ambient noise levels higher than $60 \mathrm{~dB}(A)$. The day ambient levels were observed to be higher than $65 \mathrm{~dB}(A)$ for two sites and night ambient levels higher than $60 \mathrm{~dB}(A)$ were observed for two sites in Delhi city. The comparison of ambient noise levels observed in 2015 with those observed in 2011 for the 35 stations revealed that, for some sites like Indira Nagar, PGI Hospital of Lucknow city; Kasba Gole park, Patauli and New Market site of Kolkata city; ASHP and MPCB headquarters of Mumbai city; Abids and Jeedimetla site of Hyderabad city; Eye hospital, Perambur, T. Nagar and Triplicane sites in Chennai city registered a higher increment $(\geq 5 \mathrm{~dB}(A))$ in ambient noise levels. This may be primarily due to the substantial growth of new vehicles, low turnover of old vehicles, inadequate road network and urbanization ${ }^{19-24}$.

Table 5 shows the frequency distribution of $L_{\text {day }}$ and $L_{\text {night }} ; L_{\mathrm{dn}}$ and $L_{\mathrm{Aeq}, 24 \mathrm{~h}}$ in $\mathrm{dB}(A)$ for seven major cities (70 sites) in 2015. It was observed that day levels varied from $60 \mathrm{~dB}(A)$ to $75 \mathrm{~dB}(A)$ for 49 sites $(71.0 \%)$, while the night levels varied from $55 \mathrm{~dB}(A)$ to $70 \mathrm{~dB}(A)$ for 53 sites (76.8\%). Twenty two sites $(31.9 \%)$ experienced day levels higher than $70 \mathrm{~dB}(A)$, while 9 sites $(13.0 \%)$ experienced night levels higher than $70 \mathrm{~dB}(A)$. Figure $11 a$ and $b$ shows the $L_{\mathrm{Aeq}, 24 \mathrm{~h}}$ and $L_{\mathrm{dn}}$ levels for all the 70 sites under consideration. It was observed that $L_{\mathrm{Aeq}, 24 \mathrm{~h}}$ levels range from $54.9 \mathrm{~dB}(A)$ for Hyderabad Zoo site to $84.0 \mathrm{~dB}(A)$ for Punjabi bagh site. The day-night average sound level, $L_{\mathrm{dn}}$ ranged from $58.4 \mathrm{~dB}(A)$ for Hyderabad Zoo site to $88.4 \mathrm{~dB}(A)$ for Punjabi bagh site. It was also observed from Table 5 that 56 sites $(81.2 \%)$ experienced $L_{\mathrm{dn}}$ levels $>65 \mathrm{~dB}(A)$, while 38 sites $(55.1 \%)$ experienced 

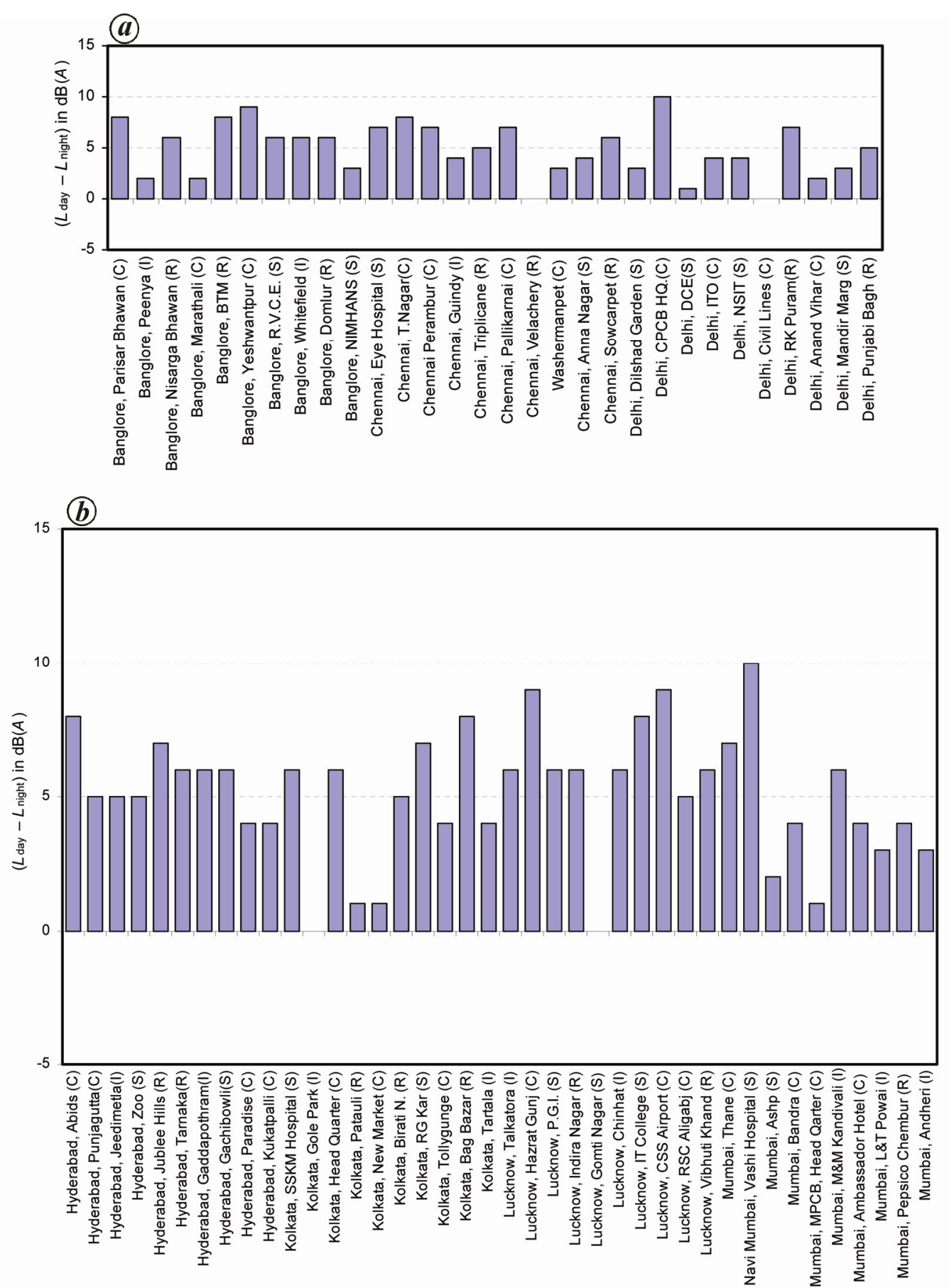

Figure 12. $\boldsymbol{a},\left(L_{\mathrm{day}}-L_{\mathrm{night}}\right)$ in $\mathrm{dB}$ at 30 locations spread across three major cities: Bengaluru, Chennai and Delhi in 2015. $\boldsymbol{b},\left(L_{\text {day }}-L_{\text {night }}\right)$ in $\mathrm{dB}$ at 40 locations spread across four major cities: Hyderabad, Kolkata, Lucknow and Mumbai in 2015.

$L_{\text {Aeq.24 }}$ levels $>65 \mathrm{~dB}(A)$. In accordance with the US Department of Housing and Urban Development (HUD) criteria $^{25}$ that recommends the $L_{\text {Aeq }} \leq 49 \mathrm{~dB}(A)$ as clearly acceptable, $49<L_{\mathrm{Aeq}} \leq 62 \mathrm{~dB}(A)$ as normally acceptable; 19 sites $(27.5 \%)$ that included 3 industrial, 2 commercial, 6 residential and 8 in silence zones met the criteria. Also, considering the criteria that $L_{\mathrm{dn}} \leq 65 \mathrm{~dB}(A)$ as acceptable, 17 sites that included 6 residential, 3 commercial, 3 in- dustrial and 5 in silence zones comply with it. These observations thus suggest a retrospective view of ambient standards limits particularly for residential and areas under silence zone in the Indian scenario. The recent study on proposed amendments in ambient noise standards of India based on single-noise descriptor proposed $L_{\mathrm{Aeq}, 24 \mathrm{~h}}$ of $70 \mathrm{~dB}(A)$ for industrial zone; $65 \mathrm{~dB}(A) L_{\mathrm{Aeq}, 24 \mathrm{~h}}$ for commercial area and mixed residential and commercial 


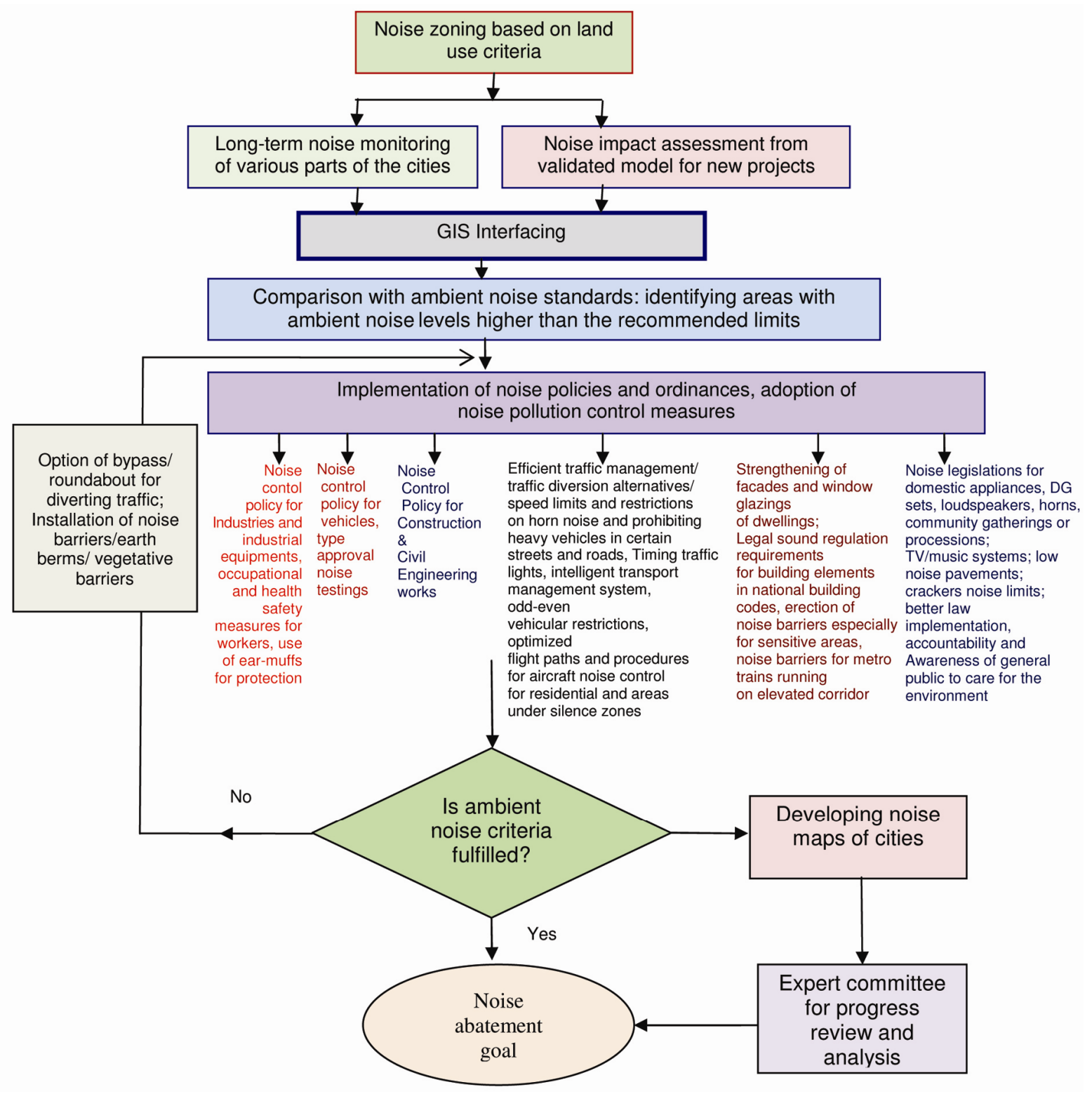

Figure 13. Flow chart of a recommended noise pollution control strategy for reducing the ambient noise levels in Indian cities ${ }^{28}$.

zones; $60 \mathrm{~dB}(A)$ for residential zone and $55 \mathrm{~dB}(A)$ for silence $z o n e^{26}$. In accordance with these criteria, 20 sites that include 5 commercial, 10 industrial, 4 residential and 1 in silence zone met the proposed standards.

Figure $12 a$ and $b$ shows the $\left(L_{\text {day }}-L_{\text {night }}\right)$ in $\mathrm{dB}$ at 70 locations spread across 7 major cities all over India in 2015. The highest value of $10 \mathrm{~dB}(A)$ was observed for Vashi hospital and CPCB head quarter site, while no difference was observed for Velachery, Civil Lines and Gole Park sites. Table 6 shows frequency distribution of difference $\left(L_{\text {day }}-L_{\text {night }}\right)$ values in $\operatorname{dB}(A)$ for all 70 sites. The analysis of $\left(\mathrm{L}_{\mathrm{day}}-L_{\mathrm{night}}\right)$ for 2015 ambient noise levels showed that $49.3 \%$ of observations showed a difference between 5 and $10 \mathrm{~dB}(A)$ and $50.7 \%$ of the observations showed a difference less than $5 \mathrm{~dB}(A)$. It may be noted that none of these sites had $\left(L_{\text {day }}-L_{\text {night }}\right)$ higher than
$10 \mathrm{~dB}(A)$. These observations also substantiate the fact that $10 \mathrm{~dB}$ night time adjustment in day-night average sound level, $L_{\mathrm{dn}}$ to account for the increased sensitivity of noise at night, the expectation that the night time noise will be lower than that during the day and for disturbance sleep protection is not appropriate in such a scenario. The numerical meta-analyses ascertaining the exposure-response relationship between community noise and cardiovascular risk recommended an empirical formulation as ${ }^{12}$

$$
\mathrm{OR}=1.63-6.13 \times 10^{-4} L_{\text {day }, 16 \mathrm{~h}}^{2}+7.36 \times 10^{-6} L_{\text {day }, 16 \mathrm{~h}}^{3}
$$

where $L_{\text {day, } 16 \mathrm{~h}}$ is the $16 \mathrm{~h}$ ambient day level and OR is the odds ratio, that are used to compare the relative odds of occurrence of the outcome of disease, given exposure to 
Table 6. Frequency distribution of difference $\left(L_{\text {day }}-L_{\text {night }}\right)$ values observed in $\mathrm{dB}$ for the 70 sites spread across the seven major cities of India

\begin{tabular}{lcc}
\hline $\begin{array}{l}\text { Variation of difference } \\
\left(L_{\text {day }}-L_{\text {night }}\right) \text { values in dB }\end{array}$ & No. of sites & $\begin{array}{c}\text { Percentage of noise } \\
\text { monitoring locations }\end{array}$ \\
\hline$-15<\left(L_{\text {day }}-L_{\text {night }}\right) \leq-10 \mathrm{~dB}$ & 0 & 0 \\
$-10<\left(L_{\text {day }}-L_{\text {night }}\right) \leq-5 \mathrm{~dB}$ & 0 & 0 \\
$-5<\left(L_{\text {day }}-L_{\text {night }}\right) \leq 0 \mathrm{~dB}$ & 0 & 0 \\
$0<\left(L_{\text {day }}-L_{\text {night }}\right) \leq 5 \mathrm{~dB}$ & 35 & 50.7 \\
$5<\left(L_{\text {day }}-L_{\text {night }}\right) \leq 10 \mathrm{~dB}$ & 34 & 49.3 \\
$10<\left(L_{\text {day }}-L_{\text {night }}\right) \leq 15 \mathrm{~dB}$ & 0 & 0 \\
\hline
\end{tabular}

the variable of interest (noise exposure level). An OR $>1$ represents exposure associated with higher odds of outcome, while an $\mathrm{OR}=1$ represents that exposure does not affect odds of outcome ${ }^{27}$. Thus, for the Punjabi bagh site in Delhi and Gole park site in Kolkata that experienced highest ambient day levels of $86.0 \mathrm{~dB}(A)$ and $81.0 \mathrm{~dB}(A)$, the odds ratio of 1.78 and 1.52 was evaluated.

The analysis of noise monitoring data for all these sites revealed that some sites immediately required a comprehensive noise abatement package for bringing the noise levels below the ambient standards. Figure 13 recommends a flow chart of a noise pollution control strategy for reducing the ambient noise levels in Indian cities ${ }^{28}$. Thus, various control measures such as appropriate land use planning and creating buffer zones for sensitive receptors; installation of noise barriers for hospitals, schools, colleges, old age homes; enforcement of maximum speed limit for heavy vehicles in residential areas; development of poro-elastic road surfaces for traffic noise control; establishment of no honking zones especially for residential and silence zones and traffic management can be instrumental in ambient noise control. However, the best practicable and economical option (BPEO) may be executed considering all these possible noise abatement alternatives ${ }^{29-37}$ for each of these sites under consideration individually.

\section{Conclusions and recommendations}

The present article describes the establishment of a diversified NANMN across seven major cities in India for continuous noise monitoring throughout the year. The annual average $L_{\text {day }}(06-22 \mathrm{~h})$ and $L_{\text {night }}(22-06 \mathrm{~h})$ values observed in the year 2015 for the 70 locations under study in which 25 locations were in commercial zone, 12 in industrial, 16 in residential and 17 in silence zones were described. The $L_{\text {day }}$ and $L_{\text {night }}$ levels observed revealed that only 10 industrial sites $(14.3 \%)$ met the ambient noise standards. It was observed that no site lying in commercial or residential or in silence zones met the ambient noise standards. The analysis of $\left(L_{\text {day }}-L_{\text {night }}\right)$ revealed that $49.3 \%$ of observations showed a difference between 5 and $10 \mathrm{~dB}(A)$ and $50.7 \%$ observations showed a difference less than or equal to $5 \mathrm{~dB}(A)$. This suggests that $10 \mathrm{~dB}$ night time adjustment in day-night average sound level, $L_{\mathrm{dn}}$ to account for increased sensitivity of noise at night with the expectation that the night time noise will be lower than that during the day and for disturbance sleep protection was not appropriate in such a scenario. The long-term noise monitoring showed that ambient noise levels were high when compared to recommended standards for some sites and thus noise abatement measures were essentially required for controlling these levels. It was observed that only 7 sites $(10 \%)$ met the target of $55 \mathrm{~dB} L_{\text {night. }}$ In accordance with the US Department of Housing and Urban Development criteria that recommends the $L_{\mathrm{Aeq}} \leq 49 \mathrm{~dB}(A)$ as clearly acceptable; $49<L_{\mathrm{Aeq}} \leq 62 \mathrm{~dB}(A)$ as normally acceptable; 19 sites $(27.5 \%)$ that included 3 industrial, 2 commercial, 6 residential and 8 silence zones met the criteria. These observations also suggest a retrospective view of ambient noise standards particularly for residential areas and areas under silence zones. The noise database presented for 70 locations under consideration will help the town administrators and planners for effective traffic management and noise control at that site. Thus, it is essential that proper selection and implementation of noise control measures as suggested in Figure 13 be executed to bring the ambient noise levels below the recommended standards. It is also recommended that further expansion of the diversified network thus established should be undertaken in these cities so as to develop noise maps of these cities; evaluate the population exposed to higher noise levels; assess the environmental noise impact over the sensitive receptors and also serve as support tool for decision-making process concerning local action plans as highlighted in recent study of Dintrans and Prénde $z^{36}$. It is also recommended that studies on noise annoyance and effect of noise on human health should be conducted in parallel exclusively for the Indian scenario so as to quantify the environmental noise impact assessment in Indian cities. Proper planning and execution of noise abatement programme shall be indispensable for reducing noise pollution in Indian cities and development of 'smart cities' project executed by the government of India. 
1. Green, M. S., Schwartz, K., Harari, G. and Najenson, T., Industrial noise exposure and ambulatory blood pressure and heart rate. J. Occup. Med., 1991, 33, 879-883.

2. Lang, T., Fouriaud, C. and Jacquinet-Salord, M. C., Length of occupational noise exposure and blood pressure. Int. Arch. Occup. Environ. Health, 1992, 63, 369-372.

3. Fogari, R., Zoppi, A., Vanasia, A., Marasi, G. and Villa, G., Occupational noise exposure and blood pressure. J. Hypertens., 1994, 12, 475-479.

4. Hessel, P. A. and Sluis-Cremer, G. K., Occupational noise exposure and blood pressure: longitudinal and cross-sectional observations in a group of underground miners. Arch. Environ. Health, 1994, 49, 128-134

5. Babisch, W., Traffic noise and cardiovascular disease: epidemiological review and synthesis. Noise Health, 2000, 2(8), 9-32.

6. Basner, M., Babisch, W., Davis, A., Brink, M., Clark, C., Janssen, S. and Stansfield, S., Auditory and non-auditory effects of noise on health. The Lancet, 2014, 383, 1325-1332.

7. Münzel, T., Gori, T., Babisch, W. and Basner, M., Cardiovascular effects of environmental noise exposure. Eur. Heart J., 2014, 35, $829-836$.

8. van Kempen, E. and Babisch, W., The quantitative relationship between road traffic noise and hypertension: a meta-analysis. J. Hypertens., 2012, 30, 1075-1086.

9. Banerjee, D., Association between transportation noise and cardiovascular disease: a meta analysis of cross-sectional studies amongst adult populations from 1980 to 2010. Indian J. Public Health, 2014, 58, 84-91.

10. Banerjee, D., Das, P. P. and Foujdar, A., Association between road traffic noise and prevalence of coronary heart disease. Environ. Monit. Assess., 2014, 186, 2885-2893.

11. Öhrström, E. and Skånberg, A., Sleep disturbances from road traffic and ventilation noise-laboratory and field experiments. J. Sound Vibr., 2004, 271, 279-296.

12. WHO-JRC. Burden of disease from environmental noisequantification of healthy life years last in Europe. European Center for Environment and Health, JRC EU, 2011.

13. Garg, N., Sinha, A. K., Gandhi, V., Bhardwaj, R. M. and Akolkar, A. B., A pilot study on establishment of ambient noise monitoring network across the major cities of India. Appl. Acoust., 2016, 103, 20-29.

14. The Noise Pollution (Regulation and Control) rules, 2000, Ministry of Environment and Forests, India; http://envfor.nic.in/ downloads/public-information/noise-pollution-rules-en.pdf

15. Geónica Earth sciences, Spain; www.geonica.com.

16. SGS Weather and Environmental Systems Pvt Ltd, New Delhi, India; http://www.sgsweather.com

17. CPCB, Ambient Noise monitoring data display site; http://www. cpcbnoise.com

18. World Health Organization, Night Noise guidelines for Europe. Copenhagen, WHO Regional Office for Europe, 2009.

19. Chowdhury, A. K., Debsarkar, A. and Chakrabarty, S., Critical assessment of day time traffic noise level at curbside open-air microenvironment of Kolkata city, India. J. Environ. Health Sci. Eng., 2015, 13, 65.

20. Sagar, T. V. and Rao, N. G., Noise pollution levels in Vishakhapatnam City (India). J. Environ. Sci. Eng., 2006, 48, 139-142.

21. Banerjee, D., Chakraborty, K. S., Bhattacharyya, S. and Gangopadhyay, A., Evaluation and analysis of road traffic noise in Asnasol: an industrial town of eastern India. Int. J. Environ. Res. Public Health, 2008, 5, 165-171

22. Goswami, S., Road traffic noise: a case study of Balasore town, Orissa, India. Int. J. Environ. Res., 2009, 3, 309-318.
23. Kisku, G. C. et al., Profile of noise pollution in Lucknow city and its impact on environment. J. Environ. Biol., 2006, 27, 409-142.

24. Joshi, A. N., Joshi, N. C. and Rane, P. P., Noise mapping in Mumbai city, India. Int. J. Innov. Sci. Eng. Technol., 2015, 2, 380-385.

25. US Department of Housing and Urban Development, Environmental Criteria and Standards, 24 CFR Part 51, Vol. 12, July 1979, amended by 49FR 880, 6 January 1984.

26. Garg, N., Kumar, A., Saini, P. K. and Maji, S., A retrospective view of ambient noise standards in India: status and proposed revision. Noise Control Eng. J., 2015, 63, 266-278.

27. Szumilas, M., Explaining odds ratios. J. Can. Acad. Child Adolesc. Psychiatry, 2010, 19, 227-229.

28. Garg, N. and Maji, S., A retrospective view of noise pollution control policy in India: status, proposed revisions and control measures. Curr. Sci., 2016, 111(1), 29-38.

29. Olayinka, O. S., Effective noise control measures and sustainable development in Nigeria. World J. Environ. Eng., 2013, 1, 5-15.

30. Garg, N., Sharma, O. and Maji, S., Experimental investigations on sound insulation through single, double and triple window glazing for traffic noise abatement. J. Sci. Ind. Res., 2011, 78, 471-478.

31. Garg, N. and Vishesh, Maji, S., Fuzzy TOPSIS approach in selection of optimal noise barrier for traffic noise abatement. Ach. Acoust., 2015, 40, 453-467.

32. Garg, N., Kumar, A. and Maji, S., Significance and implications of airborne sound insulation criteria in building elements for traffic noise abatement. Appl. Acoust., 2013, 74, 1429-1435.

33. Rasmussen, B., Sound insulation between dwellings requirements in building regulations in Europe. Appl. Acoust., 2010, 71, 373-385.

34. Garg, N., Kumar, A. and Maji, S., Parametric sensitivity analysis of factors affecting sound insulation of double glazing using Taguchi method. Appl. Acoust., 2013, 74, 1406-1413.

35. Amundsen, A. H., Klæboe, R. and Aasvang, G. M., The Norwegian facade insulation study: the efficacy of facade sound insulation in reducing noise annoyance due to road traffic. $J$ Acoust. Soc. Am., 2011, 129, 1381-1389.

36. Dintrans, A. M. and Préndez, M., A method of assessing measures to reduce road traffic noise: a case study in Santiago, Chile. Appl. Acoust., 2013, 74, 1486-1491.

37. Naish, D., A method of developing regional road traffic noise management strategies. Appl. Acoust., 2010, 71, 640-652.

ACKNOWLEDGEMENTS. We thank the CPCB authorities for permission to publish the present study. We also express our gratitude to Director, CSIR-National Physical Laboratory, India and Head, Physico Mechanical Standards for their constant encouragement and support for the research work. The present study is an extension of the previous study reported on the pilot project of establishment of NANMN project by $\mathrm{CPCB}$, India. The study was funded by $\mathrm{CPCB}$, India and Ministry of Environment and Forests (MoEF), India. Part of this work was presented at the India International Science Festival, (IISF) 2016 in December 2016. We also acknowledge the CPCB report on Status of Ambient noise levels in India (2015). The views and opinions expressed in this article are those of corresponding author's own and do not necessarily reflect the official policy or position of any agency of the Government of India.

Received 7 November 2016; revised accepted 18 April 2017

doi: $10.18520 / \mathrm{cs} / \mathrm{v} 113 / \mathrm{i} 07 / 1367-1383$ 